DEPARTMENT OF THE INTERIOR

GEOLOGICAL SURVEY

\title{
Preliminary assessment of Quaternary faulting near Truth or Consequences, New Mexico
}

\section{By}

\section{Michael N. Machette}

\section{Open-File Report 87-652}

Prepared in cooperation with the U.S. Bureau of Reclamation Denver, Colorado

This report is preliminary and has not been reviewed for conformity with

U.S. Geological Survey editorial standards and stratigraphic nomenclature.

U.S. Geological Survey

Denver, CO 80225 


\section{CONTENTS}

PAGE

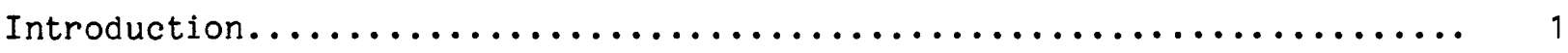

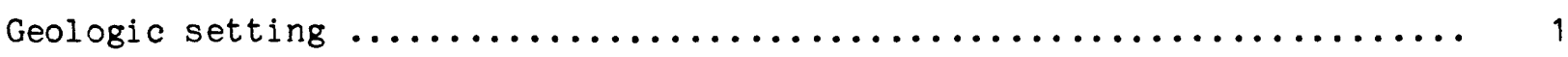

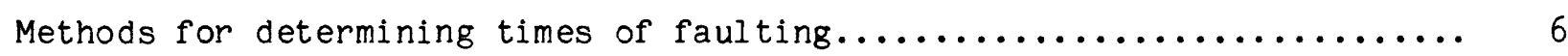

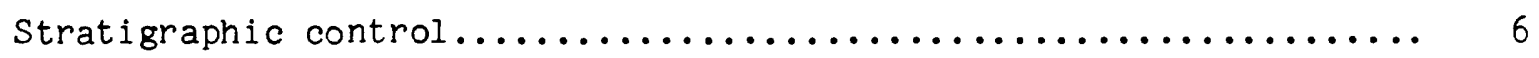

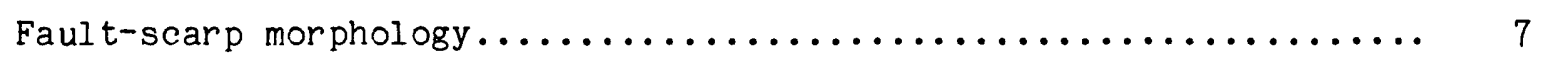

Scarp nomenclature and measurement of scarp profiles......... 8

Relation between maximum scarp-slope angle and scarp height.... 10

Compound fault scarps.......................... 11

Discussion of prominent faults near Truth or Consequences........... 13

Mulligan Gulch fault zone.................................. 13

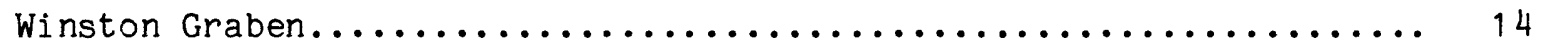

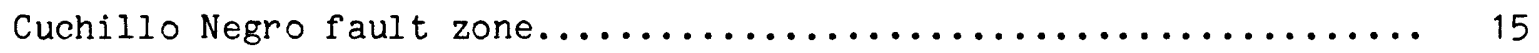

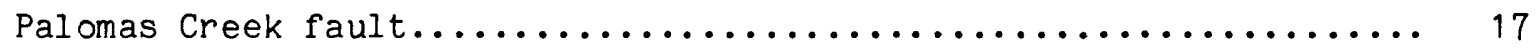

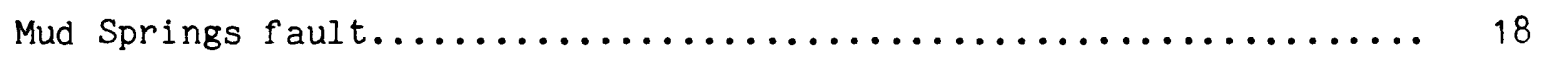

Fra Cristobal fault................................. 18

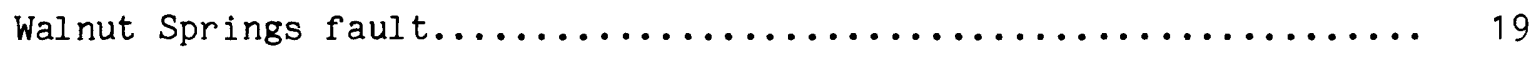

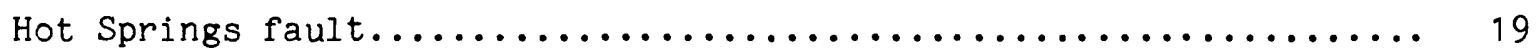

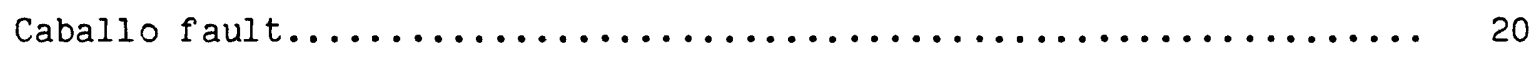

Red Hills fault............................... 28

San Andres-Organ-East Franklin Mountains fault system........... 29

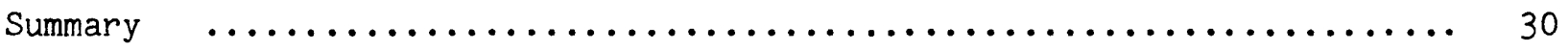

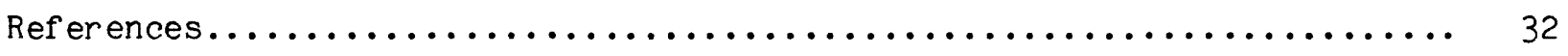

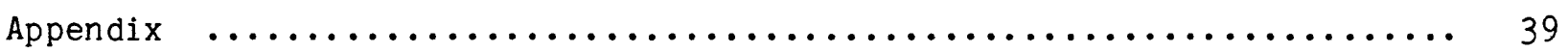

Table 1.--Data for scarps along the Caballo fault............. 40 


\section{ILLUSTRATIONS}

PAGE

FIGURE 1. Map showing major geologic features near Truth or

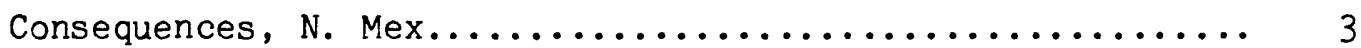

2. Diagrammatic profile of a hypothetical fault scarp......... 9

3. Maximum scarp-slope angle plotted against scarp height....... 9

4. Diagrammatic profile of a hypothetical compound fault scarp... 12

5. Maximum scarp-slope angle plotted against scarp heights...... 12

6 Map of Quaternary faults near Truth or Consequences......... 16

7. Maximum scarp-slope angle plotted against scarp height for the Palomas Creek fault scarps................... 17

8. Map showing location of scarp profiles along the Williamsburg segment of the Caballo fault............ 22

9. Map showing location of scarp profiles along the Caballo

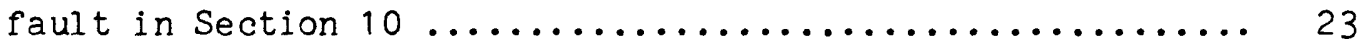

10. Map showing location of scarp profiles along the Caballo

fault near Ash Springs and Wild Horse Canyon........... 24

11. Map showing location of scarp profiles along the Caballo

fault between Granite and Flordillo Canyons............. 25

12. Maximum scarp-slope angle plotted against total scarp

height for the Caballo fault scarps................. 26

13. Maximum scarp-slope angle plotted against single- and multiple-event scarp height for the Caballo fault scarps.... 


\title{
PRELIMINARY ASSESSMENT OF QUATERNARY FAULTING NEAR TRUTH OR CONSEQUENCES, NEW MEXICO
}

\author{
By Michael N. Machette
}

\section{INTRODUCTION}

The U.S. Bureau of Reclamation is evaluating the stablility of Elephant Butte and Caballo Reservoirs, which are on the Rio Grande above and below Truth of Consequences (respectively) in south-central New Mexico. As part of this evaluation, information is needed on the recency of faulting, on the average time intervals between major earthquakes (recurrence intervals), and on evidence for possible segmentation of faults near the reservoirs.

During the summers of 1980 and 1981 , morphometric data were collected from scarps on some of the Quaternary faults near Truth or Consequences by M.N. Machette, R.G. McGimsey, and M.F. Winter of the U.S. Geological Survey. In the spring and summer of 1987, I visited several scarps localities on the Caballo fault and a trench across the williamsburg fault scarp (both are south of Truth of Consequences) with L.L. Foley of the Bureau of Reclamation (Denver). The reconnaissance work reported here is part of an ongoing study of neotectonics of the Rio Grande rift in New Mexico, southeastern Arizona, and western Texas. Several abstracts (Machette and Colman, 1983; Machette, 1987a), three 1:250,000-scale maps (Machette and McGimsey, 1983; Machette and Personius, 1984; Machette and others, 1986a), a detailed report on paleoseismicity near White Sands Missile Range (Machette, 1987b), and a preliminary compilation of Quaternary faults (Nakata and others, 1982) have been published for the rift; final compilation of about one half of the area remains to be completed. The data presented herein further defines the regional history of Quaternary faulting near Truth or Consequences, N.Mex.

\section{GEOLOGIC SETTING OF THE TRUTH OR CONSEQUENCES AREA}

The pre-Quaternary geology of the region is only briefly discussed here because this report mostly concerns evidence for Quaternary faulting. This discussion focuses on the late Cenozoic structural and stratigraphic setting of the southern Rio Grande rift, from Socorro, N. Mex., to El Paso, Tex.

(fig. 1). In addition, some relevant aspects of the bedrock geology adjacent to major Quaternary faults near Truth or Consequences are discussed in regards to possible structural controls on fault geometry and fault segments and to amounts of net displacement across the faults. There are a number of comprehensive reports on this area, which include lengthy discussions of the evolution of the Rio Grande rift (Chapin and Seager, 1975; Bachman and Mehnert, 1978; Chapin, 1979; Cook and others, 1979; Riecker, 1979; Seager and Morgan, 1979; Seager and others, 1984), guidebooks (edited by Fitzsimmons, 1955; Seager and others, 1975; Hawley, 1978; and $\mathrm{Cl}$ emons and others, 1986), as well as regional maps (compiled by Woodward and others, 1978; Nakata and others, 1982; Baldridge and others, 1983) and detailed maps (Seager and others, 1982, 1987; Heyl and others, 1983; Lozinsky, 1986; and Maxwell and Oakman, 1986). The recent article on the geology of the Truth or Consequences area by Clemons and Osburn (1986) provides a convenient overview of the region. The following discussion presents a broad overview of the Rio Grande 
rift in central and southern New Mexico, the timing of the rift's inception, and its subsequent development during the late Cenozoic. Evidence for Quaternary faulting near Truth or Consequences is presented in view of the region's structural and geologic setting.

Initial rifting began 26-28 Ma in southern New Mexico (Chapin and Seager, 1975), as regional extension reactivated Paleozoic and Mesozoic zones of weakness (mainly faults and folds) in the Southern Rocky Mountains province. A series of broad, northwest-trending, fault-bounded basins had formed by 26 $\mathrm{Ma}$; these basins were filled in the Miocene by mafic flows, rhyolitic ash-flow tuffs, and locally derived alluvium. Seager and others (1984) postulated that this initial episode of rifting was in a back-arc setting, and was followed by period of renewed rifting during the late Miocene and Pliocene (9-3 Ma).

Quaternary and Pliocene faults, dikes, and volcanic vents throughout the Rio Grande rift generally are oriented north-south, whereas Miocene faults and volcanic features commonly have a northwest orientation (Zoback and Zoback, 1980; Zoback and others, 1981; Aldrich and Laughlin, 1982; Laughl in and others, 1983; Lipman, 1983). These orientations strongly imply as much as $30^{\circ}$ of clockwise rotation of the axis of least-principal stress during the past 30 $\mathrm{Ma}$ (Machette and Colman, 1983) Epeirogenic uplift of the region and blocking out of the north-trending basins and uplifts of the modern Rio Grande rift occurred during the latest period of extension.

Chapin and others (1978) mapped a transverse shear zone that extends through the Socorro area and trends east-northeast (STSZ, fig. 1 in Machette, 1987b). This feature, previously known as the Morenci lineament, marks a zone of differential rotation and step faulting, across which normal faults have opposite directions of displacement (north side--down to the east, south side- down to the west). This same relation is shown in major structural blocks: north of the zone, mid-Tertiary and older rocks of the Socorro and Lemitar Mountains, which bound the west side of the Rio Grande rift north of Socorro, dip steeply to the west, whereas in the Chupadera Mountains (southwest of Socorro and the transverse shear zone) the same age rocks dip to the east. This zone coincides with an apparent right step in the axial graben of the Rio Grande rift--a relation analogous with the half grabens of the northern Rio Grande rift which change tilt direction where the Jemez lineament crosses the Rio Grande rift (Muehlberger, 1979; Machette and Personius, 1984).

The rift changes from a single, narrow graben in the Socorro area, to several grabens (basins) and horsts (ranges) that are approximately 2.5 times wider than to the north. South of Socorro, the Rio Grande rift is expressed as three well defined graben systems: a western arm (the Winston graben); the central (axial) rift which extends from Socorro into the San Marcial, Engle, and Palomas basins; and an eastern arm (Tularosa and Hueco Basins) that extends almost $200 \mathrm{~km}$ south into Mexico (Ramberg and others, 1978; Seager and Morgan, 1979). The Rio Grande flows down the axial graben in the Socorro area, and south through the San Marcial, Engle, and Palomas Basins in southern New Mexico. 


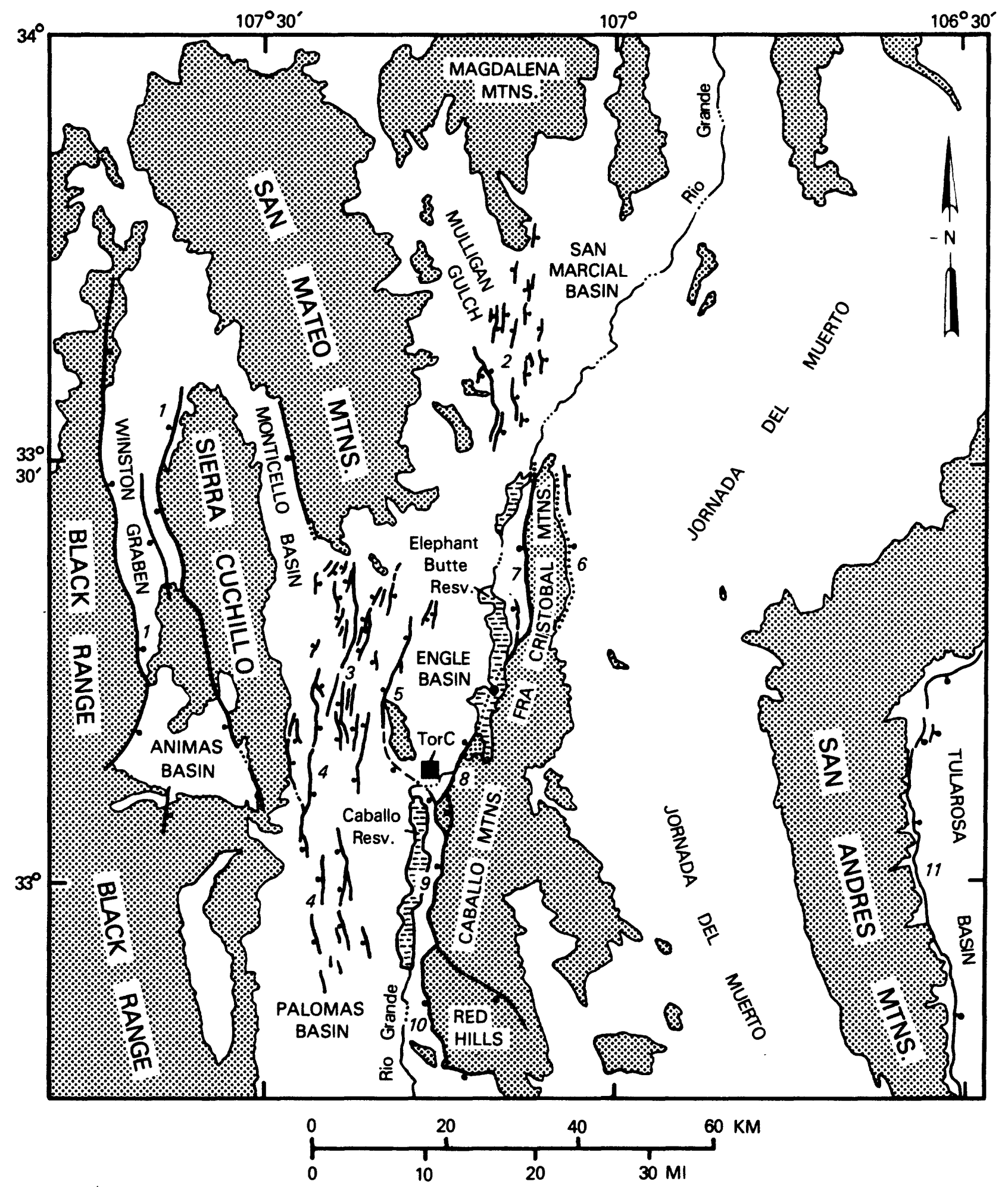

FIGURE 1.--Map showing geologic and geographic features near Truth or Consequences ( $T$ or $C$ ), New Mexico. Miocene and older rocks shown by stipple pattern. Major Quaternary faults are shown by heavy line with bar-ball symbol on downdropped side. Numbers refer to faults discussed in text. 
Gravity and heat-flow data suggest that the Rio Grande rift is underlain by an asthenospheric upwarp that has thinned the crust throughout the length of the rift; the change to a dispersed graben system may be related to widening of this mantle upwarp from the Socorro area southward (Ramberg and others, 1978; Seager and Morgan, 1979). The surface expression of the Rio Grande rift probably is influenced by the type of physiography surrounding it; in central and northern New Mexico the rift is a single half or full graben bounded by stable regions of the Colorado Plateaus province to the west and the Great Plains province to the east. However, in southern New Mexico the rift is bounded by Tertiary volcanic fields (the Datil-Mogollon field in western New Mexico and the Trans Pecos field in westernmost Texas): in this region the broadened rift has topography similar to that of the Basin and Range province of Arizona (Cook and others, 1979). Although some authors believe that the Rio Grande rift merges imperceptibly with the Basin and Range province in southern New Mexico (Kelley, 1955; Elston and Bornhorst, 1979), recent geophysical data seems to infer the continuation of the thermotectonic conditions characteristic of the northern Rio Grande rift (for example, high heat flow, Quaternary faulting and volcanism, presence of deep basins) into southern New Mexico, westernmost Texas, and northern Mexico (Ramberg and others, 1978; Cook and others, 1979; Seager and Morgan, 1979). Most of the Basin and Range structures of southeastern Arizona have been inactive in late Quaternary time (Machette and others, 1986a), whereas rift-related structures in southern $\mathrm{N}$. Mex. have been active.

In southern New Mexico, the eastern expression of the Rio Grande rift is marked by the Tularosa and Hueco Basins, which are bordered by the east-tilted Sacramento Mountains to the east and the west-tilted San Andres, Organ, and Franklin Mountains to the west ( $f i g .1$ ). Both basin margins are marked by high-angle normal faults, which show substantial Pliocene and Pleistocene displacement (see discussion of Quaternary faulting by Machette, 1987b). The abundance of Quaternary faults and thickness of upper Cenozoic sediments found in this elongate basin indicate a long period of active extension and uplift, as suggested by Seager and Morgan (1979).

The Jornada del Muerto Basin lies between the Tularosa-Hueco and PalomasEngle Basins, just east of the central rift of the Rio Grande. This basin is bounded on the west by the Caballo and Fra Cristobal Mountains and on the east by the San Andres Mountains; each of the bounding ranges are tilted into the basin. The Jornada del Muerto is formed by an elongate syncline (Kelley and Silver, 1952) that contains gently folded middle Tertiary rocks, indicating the basin probably formed in late Tertiary in response to rifting and uplift of the adjacent ranges (Seager, 1986, p. 44). Because only sparse and relatively minor Quaternary faulting is found along the basin's west margin, most of the structural relief is from gentle folding (see cross section of Lozinsky, 1987). The central rift basins (San Marcial, Engle and Palomas basins) are bound on the east by major faults at the west base of the Fra Cristobal and Caballo Mountains. These ranges and those adjacent to the Tularosa/Hueco Basins are composed predominately of Precambrian and Paleozoic with Mesozoic sedimentary rocks locally preserved on the back slopes of some ranges and in the Cutler sag, a structurally low area between the Fra Cristobal and Caballo Ranges. 
The central rift is marked by a series of normal faults that cut middle to late Pleistocene alluvial deposits within and along the east side of the San Marcial, Engle, and Palomas Basins. In addition, the west half of these basins have intrabasinal faults, most of which dip west. In contrast to the eastern margin, only a minor part of the west margin of the central rift graben is controlled by faults that show late Quaternary movement, thus the central rift is more likely a lop-sided half graben (deepest on the east side; see Lozinsky, 1987, fig. 2). The Winston graben, which is the westernmost arm of the Pliocene to Pleistocene age Rio Grande rift, trends north-northwest in contrast to the normal north-alignment of the rift's other basins. Faults that bound the Winston graben show no evidence of Quaternary movement and little evidence of substantial Pliocene displacement. The basin and adjacent range topography of the Winston graben is probably an artifact of late Miocene to early Pliocene extension along older Cenozoic (early rift-related) faults.

The thick basin-fill deposits of the Santa Fe Group preserved within the grabens of the southern Rio Grande rift provide a stratigraphic record of faulting during the Miocene to the middle Pleistocene. North of Las Cruces, N. Mex., the Miocene Hayner Ranch and Rincon Valley Formations of the lower part of the Santa Fe Group (Hawley and others, 1969; Seager and others, 1982; Chapin and Seager, 1975) record the depositional response to initial rifting. These and coeval units exposed near Socorro (primarily the Popotosa Formation; Machette, 1978) were deposited in a series of 1 arge bolsons (closed basins) which have been locally uplifted and exposed by younger rifting.

Renewed extension coupled with regional epeirogenic uplift and an increase in runoff in the early Pliocene (Chapin, 1979) allowed the Rio Grande to become a major integrated stream that flowed from southern Colorado and New Mexico to northern Mexico, where the river emptied via a delta complex into a large lake basin. The Rio Grande and its tributary streams traversed and filled a series of elongate depressions (Hawley and Kottlowski, 1969; Hawley and others, 1969, 1976) as it deposited a thick sequence of Pliocene and Pleistocene fluvial, bolson, and deltaic sediments (upper part of the Santa $\mathrm{Fe}$ Group), which locally are mapped as the Camp Rice Formation of Strain (1966), the Palomas Formation of Lozinsky and Hawley (1986), and the Sierra Ladrones Formation (Machette, 1978). Sediments of the upper Santa Fe Group contain basalts as old as 4.5 Ma (Machette, 1978) as well as Pliocene (Blancan) vertebrate fossils (Lucas and Oakes, 1986; Reppening and May, 1986). Deformation during or prior to the early Pliocene created an angular unconformity that locally separates the upper and lower parts of the Santa Fe Group, especially along the margins of the rift basins.

Along the upper reach of the ancestral Rio Grande (those parts in New Mexico and Colorado), aggradation in the rift basins continued from $4-5 \mathrm{Ma}$ to about 0.7-0.5 Ma (Seager and others, 1984), when the upper and lower reaches of the Rio Grande became connected at El Paso, Tex. The Sierra Ladrones, Palomas, and Camp Rice Formations, are equivalent units in the upper part of the Santa $\mathrm{Fe}$ Group, al though these formation names are restricted to the Albuquerque, San Marcial-Engle-Palomas, and Mesilla basins, respectively. The constructional top of the upper Santa Fe Group is preserved as widespread relict basin floor and piedmont slope surfaces 100-200 m above the Rio Grande and its major tributary streams (Bachman and Mehnert, 1978; Gile and others, 1981). Integration of the upper and lower reaches of the Rio Grande caused a drastic drop in base level along the upper Rio Grande; as a result the Rio 
Grande and its tributaries subsequently have deeply into basin-fill sediment and the underlying bedrock. The topography of the modern Rio Grande Valley is strongly controlled by this period of middle Pleistocene incision.

West of the Rio Grande, the medial and distal parts of two huge, coalesced middle Pleistocene alluvial-fan and piedmont aprons--the Cuchillo and Palomas surfaces--spread eastward from the Black Range, Sierra Cuchillo, and the San Mateo Mountains (Lozinsky, 1986). East of the river, the Jornada del Muerto (Spanish: journey of death) and Tularosa-Hueco Basins remain as largely undissected alluvial basin floors. These surfaces are pieces of a previously widespread, and still relatively stable landform that is now stranded above incised tributaries of the Rio Grande. Thus., parts of these basins have been isolated from major aggradation or downcutting since the Rio Grande became entrenched in its present valley. In these largely undissected basins and along the deeply entrenched valley of the Rio Grande, the bulk of the surficial materials are of late Pleistocene and Holocene age.

\section{METHODS FOR DETERMINING TIMES OF FAULTING}

Two methods are used in this study to determine the times of fault movement. The first method is a stratigraphic approach by which the ages of the youngest faulted and oldest unfaulted deposits bracket the time of the most recent fault movement. Recurring episodes of movement are of ten recognized by comparing the cumulative amounts of displacement in deposits of different age. A second method is to infer ages of undated fault scarps through a quantitative comparison of their morphology with that of dated scarps. This latter method is discussed in the section entitled "Fault-Scarp Morphology."

\section{Stratigraphic Control}

For reconnaissance work in south-central New Mexico, the surficial and young basin-fill deposits and faults in the map area were compiled from reports by Kelley (1955), Kottlowski (1955), and Seager (1980, 1981), and from examination of aerial photographs. Since completing the fieldwork, Seager and others (1982 and 1987) published maps at $1: 125,000$ scale that show the surficial and bedrock geology of the northern part of the Las Cruces $1^{\circ} \times 2^{\circ}$ quadrangle (about $25 \mathrm{~km}$ south of Truth or Consequences), whereas Lozinsky (1986) and Maxwell and Oakman (1986) have published detailed mapping in the Truth or Consequences area and Mud Springs Mountains, respectively. Much of the new mapping has been incorporated into this study.

For reconnaissance mapping, the Pliocene and younger deposits were divided into four categories to provide control on times of fault movement. The oldest category, of Pliocene and early Pleistocene age (5.0-0.75 Ma), includes some of the younger basaltic rocks of the region, and deposits of the Camp Rice Formation of Strain (1966) and Palomas Formation of Lozinsky and Hawley (1986). The middle Pleistocene (0.13-0.75 Ma) category includes deposits that form the constructional surface of the Camp Rice and Palomas Formations, which were abandoned about 0.5-0.7 Ma (Hawley and others, 1976; Seager and others, 1984), and the older of the subsequent valley-fill alluvial units. The latter deposits include units correlative with the Jornada I and Tortugas alluviums of Hawley and Kottlowski (1969) in southern New Mexico and alluvium of terrace levels 1 and 2 of Lozinsky (1986) near Truth or Consequences. The upper Pleistocene $(130,000-10,000$ yr ago) category includes 
deposits correlative with the Jornada II, Picacho, Isaack's Ranch, and Leasburg alluviums of Hawley and Kottlowski (1969) and alluvium of terrace levels 3-5 of Lozinsky (1986). The youngest category includes Holocene $(<10,000 \mathrm{yr}$ ) alluvium of the lowest terraces and modern floodplain (Fillmore alluvium of Hawley and Kottlowski, 1969; Holocene valley-fill alluvium of Lozinsky (1986), young alluvial-fan deposits (Organ alluvium of Hawley and Kottlowski, 1969), and eolian sand.

Because surficial deposits have not been mapped in detail along many of the Quaternary faults near Truth or Consequences, ages of the deposits were estimated from preservation of landforms, degree and density of dissection, stratigraphic and topographic position, and soil development (see Birkeland, 1984, and Machette, 1985 for a discussion of dating criteria and methods). Although this investigation is mainly of a reconnaissance nature, I am fairly confident that most of the age estimates for faulted and unfaulted deposits are reasonable because each category represents a broad range of geologic time (tens of thousands to hundreds of thousands of years).

\section{Faul t-Scarp Morphology}

Stratigraphy and relative-dating techniques provide the chronologic framework for the Quaternary and Pliocene deposits that record faulting. The faulting may be considerably younger than the deposits that are affected (for example, a 5-ka scarp on 100-ka alluvium). However, analysis of fault-scarp degradation has given us a new tool that is appropriate for both reconnaissance and detailed investigations of iaulting. This technique uses morphometric data from profiles of normal-fault scarps to determine the time elapsed since scarp formation. The empirical basis of this technique is simple: for two different-age scarps of comparable height and material (for example, a sandy gravel), the older scarp is the one having the more subdued topography, in terms of both slope and curvature. Calibration for determining the age of the fault scarp comes from other scarps and similar geomorphic features (shorelines and fluvial-terrace scarps) that are dated by radiometric or stratigraphic methods. This approach provides the time of the fault-scarpforming event (earthquake) itself, rather than an age for a geomorphic surface or stratigraphic layer that may only broadly limit the time of last movement.

The approach used in this reconnaissance study is based on Bucknam and Anderson's (1979) empirical relation between the height of a fault scarp ( $H)$ and its maximum scarp-slope angle $(\theta)$, which built upon Wallace's (1977) studies of slope-degradation processes and morphology of fault scarps. The scarp-morphology data presented in the following discussion show the relation between fault-scarp height and maximum scarp-slope angle, the variation of these two parameters, and their relation to fault scarps of known age. My studies are based on the following premises of fault-scarp evolution: (1) initially, the free face of the fault scarp is near vertical, reflecting the near-surface dip of the fault; (2) soon the face slumps to the angle of repose of the faulted material, typically $32^{\circ}-35^{\circ}$ for unconsolidated surficial deposits; and (3) then the slope of the scarp decreases at a slower rate, mainly by the process of slopewash instead of gravitional collapse (Wallace, 1977; Nash, 1981; Pierce and Colman, 1986). Only those fault scarps on unconsolidated Quaternary deposits have been analyzed. Most of the fault scarps studied are on pebbly sand to sandy gravel alluvium, material that is generally of the same texture as scarps studied by Bucknam and Anderson (1979). 
Scarp nomenclature and measurement of scarp profiles

The heights of fault scarps were determined from detailed topographic surveys made along traverses perpendicular to the scarps. I used a vernierscale hand level and Jacobs staff, cloth tape, and stadia rod to measure slope angles across the scarp. These traverses extended 20-100 m above and below the fault scarp in order to determine the slopes of the adjacent alluvial surfaces. Measurements were made at intervals of 2-5 $\mathrm{m}$ on the upper and lower slopes and at intervals of $0.5-2 \mathrm{~m}$ on the scarp.

The nomenclature used in this report is modified only slightly from that used by Bucknam and Anderson (1979). Scarp height ( $\mathrm{H}$, in meters; fig. 2 ) is the vertical distance between the surfaces above and below the scarp where intersected by the plane representing the maximum scarp-slope angle $(\theta)$. The angles $\theta$ and $\gamma$ denote the inclination from horizontal of the scarp and the adjacent land surfaces, respectively. Thus, each traverse yielded a scarp profile and each profile yielded a value for $\mathrm{H}$ and $\theta$ (a data pair). The maximum scarp-slope angle was measured over a length equal to 10-20 percent of the distance between the crest and toe of a scarp at four to six sites within 3-5 $\mathrm{m}$ of each traverse line. Values of $\theta$ reported here are the average of the repeated measurements; this averaging is necessary to minimize uncharacteristic determinations of $\theta$. (The data on $\theta$ collected by L.L. Foley represent a single determination of the maximum slope values. In some cases, I have used a different value of $\theta$ for the analysis of morphometric data.).

At least seven data pairs are needed for statistical analysis. Data sets smaller than seven may or may not represent the morphology of a fault scarp accurately; however, these smaller data sets still are useful for showing local variations in height and steepness along the length of a fault scarp, and for characterizing the general morphology of a fault scarp.

The height and maximum scarp-slope angle of an individual scarp are measured at several places along its length. Most height measurements are from 1 to $10 \mathrm{~m}$ (the useful range), but some older scarps are as high as $30 \mathrm{~m}$. I chose sites that are relatively stable (geomorphologically) by avoiding areas of active erosion or deposition. Parts of the Cuchillo and Palomas surfaces west of Truth or Consequences are covered by eolian sand that renders them unsuitable for studies of fault-scarp morphology. In addition, the scarps formed by intrabasin faults that dip upslope (to the west) often are partially buried by stream alluvium. If the burial is recent compared to the age of the scarp, a scarp will appear more degraded (older) than a downslope-facing unburied scarp of the same age. Scarps along segmented faults (segments are sections of faults that each have a discrete history of surface rupture) were treated morphometrically as individual scarps

Major factors that affect the rate of scarp degradation include the texture and cohesion of the faulted deposits, orientation and height of the scarp, and the climate, vegetation, biologic activity, and topographic relief at the scarp site (see Pierce and Colman, 1986, for a discussion of some of these factors). I chose profiling sites where these factors were as uniform as possible so that observed differences in scarp morphology would largely reflect the age of a scarp. Although variations exist between some scarps, especially in the texture of the faulted deposits, the measurements presented here represent typical fault scarps in the area. 


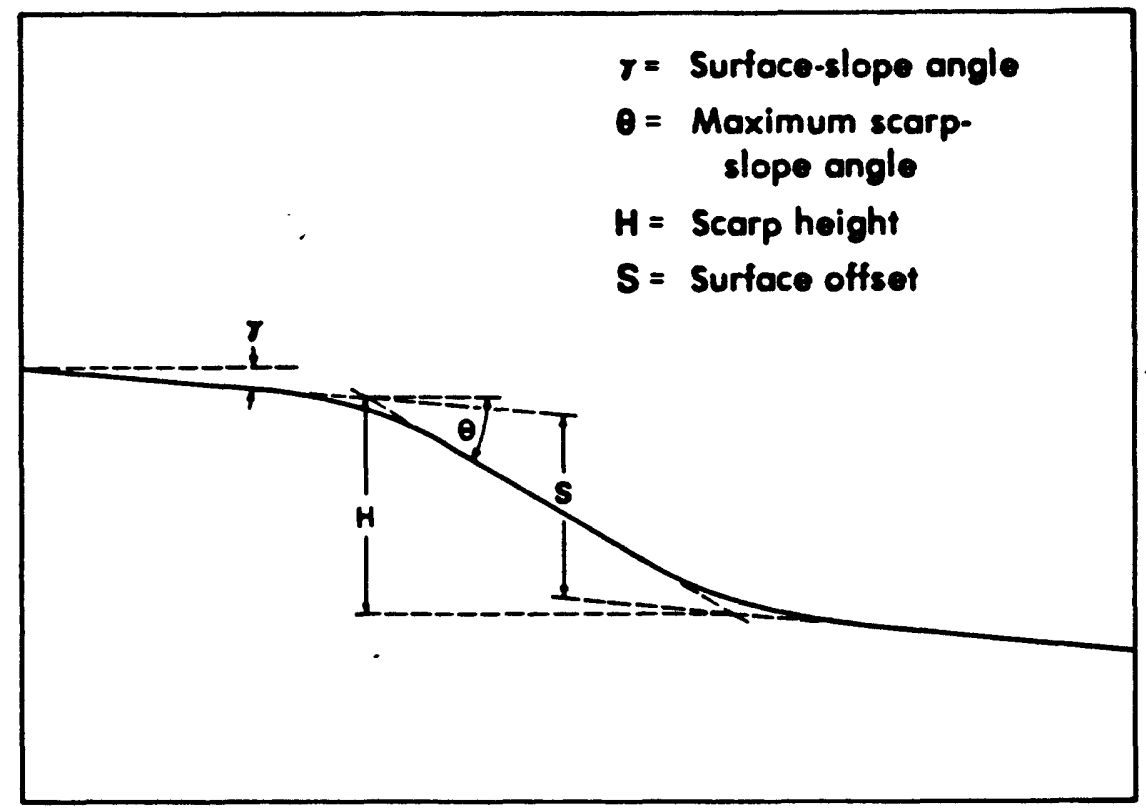

FIGURE 2.--Diagrammatic profile of a hypothetical fault-scarp (modified from Bucknam and Anderson, 1979, fig. 1).

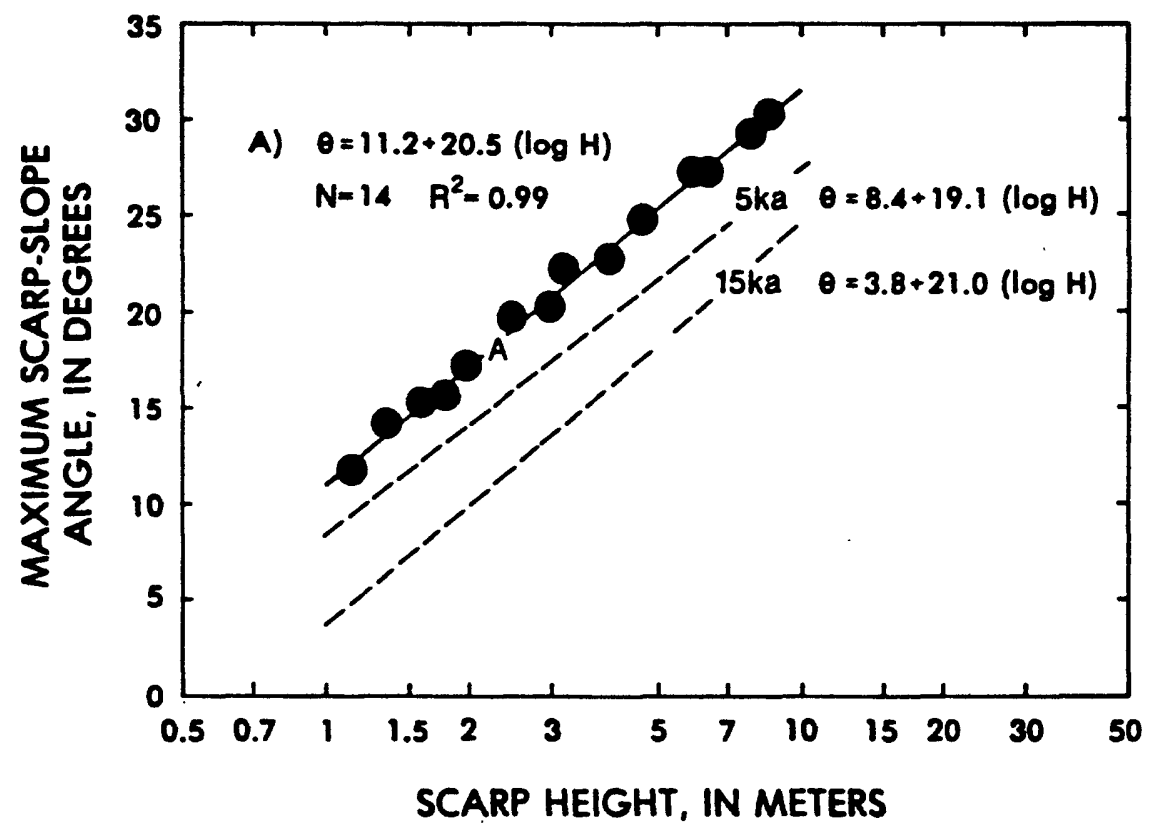

FIGURE 3.--Maximum scarp-slope angle $(\theta)$ plotted against scarp height (H) for a hypothetical fault scarp (from Machette and others, 1986a). Also shown are the number of data pairs $(n)$, the coefficient of determination $\left(r^{2}\right)$, two reference lines for age comparisons ( 5 ka--La Jencia fault of central New Mexico; $15 \mathrm{ka--Bonneville} \mathrm{shorel} \mathrm{ine} \mathrm{of} \mathrm{Utah),} \mathrm{and} \mathrm{equations} \mathrm{for} \mathrm{their}$ lines of best $f$ it. 
Relation between maximum scarp-slope angle

and scarp height

The studies of Bucknam and Anderson (1979) showed that there is a positive correlation between the heights of scarps $(H)$ of a given age and their maximum scarp-slope angle ( $\theta$, fig. 3$)$. The relation holds for a wide range of heights and slope angles (see recent discussion of Pierce and Colman, 1986) and also applies to fluvial scarps and wave-cut shorelines, such as those formed during the highest stand of Lake Bonneville in Utah. Although the Lake Bonneville shoreline escarpment is an erosional feature, Bucknam and Anderson (1979) consider that it eroded much like a fault scarp. The main difference in these two genetically different features is that a fault scarp requires a initial time interval for the free face to collapse to the angle of repose, whereas a shoreline escarpment probably has an initial scarp-slope angle that is equal to the angle of repose (instead of nearly vertical). The time required for the scarp to degrade in such a manner has not been determined, but the degree of erosion of historic scarps in the Basin and Range province suggests that phase may take several hundred to perhaps a thousand years.

The empirical relation for analyzing scarp morphology is based on a least-squares linear regression equation of the form $\theta=a+b(\log H)$ (where $a$ is the value of $\theta$ when $\mathrm{H}=1 \mathrm{~m}$, and where $\mathrm{b}$ is the slope of the line). Bucknam and Anderson (1979) found that 91 percent of the variation in 61 measurements of $\theta$ and $\mathrm{H}$ from the Bonneville shoreline is explained by the $\theta=3.8+21.0$ (log $\mathrm{H}$ ) (Bucknam, 1980). They also found that scarps younger and older than the Bonneville shoreline have similar relations, but plot in respectively higher and lower parts of the graph of $\theta$ versus $H$. The presentation of scarpmorphology data in this report follows the style of Bucknam and Anderson (1979) as illustrated in figure 3, which shows hypothetical fault scarp data. In this and other similarly constructed figures, data points are shown as circles or squares depending on the type of height data being plotted. Table 1 (see Appendix) shows the basic scarp-morphology data for some of the major Quaternary faults near Truth or Consequences; if there were an adequate number of data points, I also calculated the equation for the line of best $f$ it and the coefficient of determination.

In reconnaissance studies of fault scarps in the Rio Grande rift there are three general conditions for which $\mathrm{H}$ and $\theta$ do not correlate very well. The first involves fault scarps having maximum scarp-slope angles $(\theta)$ that are only a few degrees steeper than the adjoining land surfaces; such scarps generally have a weak correlation between $\mathrm{H}$ and $\theta$ and $a$ low value for the slope of the line of best fit (the value b). These scarps are either very small ( $<0.5 \mathrm{~m}$ ) or are fairly old (for example, tens to hundreds of thousands of years since last movement). This condition applies to many of the intrabasin faults in the area. The second condition involves scarps formed by faulting of surfaces having gradients ( $\gamma$, fig. 3) of more than about $5^{\circ}$. Steeply sloping surfaces are usually associated with locally derived alluvial fans near the front of mountain ranges. This setting, which applies mainly to the Caballo fault, can cause the scarp to be anomalously steep and thus yield erroneously young age relations. The third condition involves young scarps having slope angles that exceed the angle of repose of the faulted material. In this case, the empirical relations will apply only to small scarps that have slopes less than the angle of repose, whereas larger scarps will have 
slope angles that cluster about the angle of repose. None of the scarps near Truth or Consequences seem to be young enough (i.e., several thousand years) to have slope angles that approach the angle of repose.

The methods and results of Bucknam and Anderson (1979) and Machette and McGimsey (1983) were used to assign relative ages to fault scarps. For calibration I used the lines of best fit for data from two scarps of known age that are shown in figure 3. This figure (and a similar presentation in fig. 5) is the basis for comparison of morphometric data throughout this report. The uppermost dashed line (labeled $5 \mathrm{ka}$ in figs. 3 and 5) represents data from segment $C$ of La Jencia fault near Magdalena, N. Mex. (most recent movement about $5 \mathrm{ka}$; Machette and McGimsey, 1983; Machette, 1986). This data set is represented by the equation, $\theta=11.2+20.5(\log \mathrm{H})$. The second dashed line (labeled $15 \mathrm{ka}$ in figs. 3 and 5) is based on Bucknam's (1980) data from the highest wave-cut shoreline of Lake Bonneville, Utah, which is here considered to have formed about $15 \mathrm{ka}$ on the basis of stratigraphic and radiometric studies by Scott and others (1983). The regression equation for the Lake Bonneville shorelines is $\theta=3.8+21.0(\log \mathrm{H})$.

I use the following criteria to assign relative ages to fault scarps from morphometric data: scarps having (1) lines of best fit above the upper dashed line on figure 3 ( $5 \mathrm{ka}$ ) are considered to be of Holocene age (less than 10 $\mathrm{ka})$; (2) lines of best fit between the two dashed lines indicate scarps of Holocene or latest Pleistocene age (less than $35 \mathrm{ka}$ ); and (3) lines of best fit to the right of and below the lower dashed line (15 ka) indicate scarps of late Pleistocene age $(10-130 \mathrm{ka})$ or, less likely, of middle Pleistocene age $(130-750 \mathrm{ka})$.

\section{Compound fault scarps}

Many of the scarps of range-bounding faults in the region, even those as small as $5 \mathrm{~m}$ of surface offset, were formed by several faulting events as shown by (1) increasing scarp heights in progressively older deposits or (2) by scarps that have discrete facets--that is, compound-slope angles (fig. 4; Wallace, 1977). These multiple-event or "compound" scarps commonly have the form of degraded fault scarps that have been reactivated one or more times (the older scarp surfaces are denoted by the angle $\theta^{\prime}$, fig. 4). The morphology of some compound scarps can be analyzed by assuming that the steepest element of the scarp (shown by $\theta$ and Hs in $\mathrm{fig}$. 4) was formed during the most recent faulting and that the remaining less-steep parts, marked by bevels, represent previous faulting events and erosion. In such cases, Hs is defined as the difference in elevation between the beveled scarp surfaces $\left(\theta^{\prime}\right)$ where intersected by the plane of the maximum slope angle $(\theta)$. (Although this treatment violates the second of three conditions--that slope gradients should be $\left\langle 5^{\circ}-\right.$ it is the most appropriate way to interpret compound scarps.)

If a plot of Hs versus $\theta$ for a compound scarp and a plot of $H$ versus $\theta$ for a single-event scarp along the same fault yields similar relations, the subdivision of faulting elements is appropriate. When treated in this manner, compound fault scarps yield values for Hs versus $\theta$ ( $f$ ig. 5) that plot considerably higher (younger) than the data for Hm versus $\theta$, and thus are better indicators of the recency of faulting than that indicated by total scarp height ( $\mathrm{Ht}$ or $\mathrm{Hm}$ ). Profiles across compound scarps can yield three different scarp heights: Hs, single event; Hm, multiple event (compound part); and Ht, total scarp height (see table 1). 


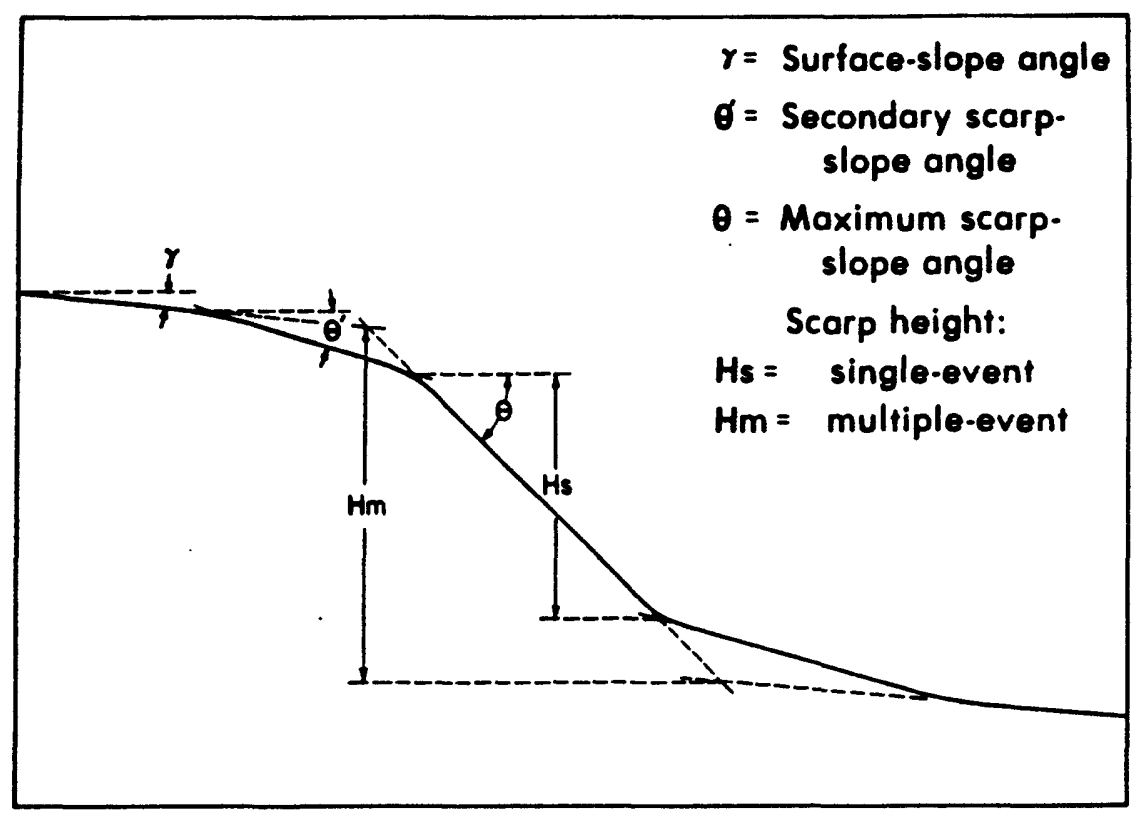

FICURE 4.--Diagrammatic profile of a hypothetical compound fault scarp (from Machette and others, 1986a).

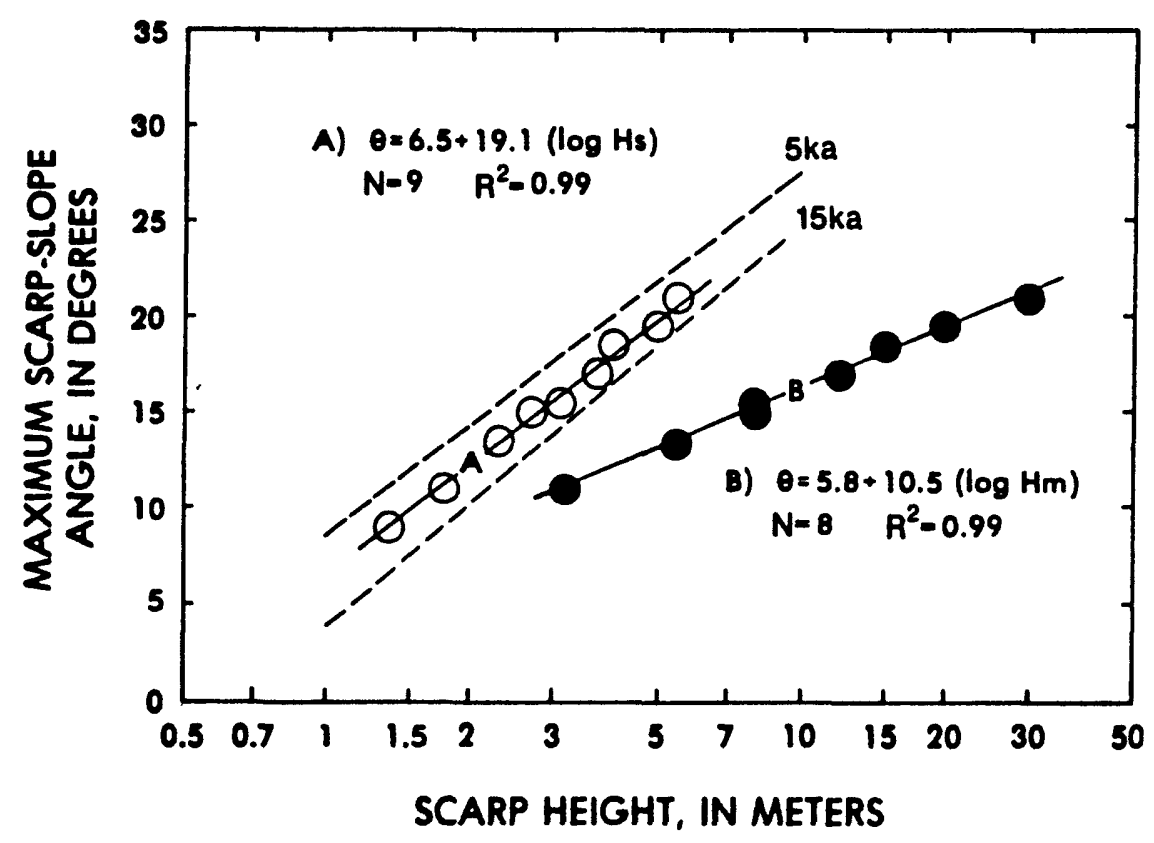

FIGURE 5.--Maximum scarp-slope angle $(\theta)$ plotted against scarp heights (Hs-open circles and Iine A; Hm--filled circles and line B) for a hypothetical compound fault scarp (from Machette and others, 1986a). Also shown are the number of data pairs $(n)$, the coefficient of determination $\left(r^{2}\right)$, two reference lines for age comparisons ( $5 \mathrm{ka}$ and $15 \mathrm{ka}$ ), and equations for their lines of best fit. 
The resultant $l$ ine of best $f$ it for the youngest element of a scarp ( $\theta$ vs. Hs) commonly has a steeper slope (larger value for b in the regression equation) than does the data for the compound part of a fault scarp (Hm) or for the total height of a scarp ( $\mathrm{Ht}$; plotted as filled squares in some figures). In addition, the $b$ value for a plot of Hs versus $\theta$ for a compound scarp is similar to those of $\theta$ versus $H$ for single-event scarps. From these relations it is reasonable to infer that fault-scarp data represented by a line of best fit having a low b value might indicate multiple episodes of faulting even though the scarp may not have obvious compound slope angles.

Fault scarps as much as $20-60 \mathrm{~m}$ high clearly record ten's of individual faulting events because historic single-event scarps in the Western U.S. are commonly less than 2-4 m high. Compound angles (bevels) generally are preserved only when the most recent faulting event(s) is young compared to prior events (for example, $5 \mathrm{ka}$ versus $25 \mathrm{ka}$ ). However, if the time of the most recent faulting (for example, $15 \mathrm{ka}$ ) approaches the time interval between faulting events (recurrence interval; $20 \mathrm{ka}$, prior event $35 \mathrm{ka}$ ) then the scarp formed by the most recent faulting will blend imperceptibly into the older scarp.

\section{DISCUSSION OF PROMINENT QUATERNARY FAULTS NEAR TRUTH OR CONSEQUENCES}

The following discussion focuses on evidence for Quaternary movement on prominent faults and fault zones (or systems) near Truth or Consequences, $N$. Mex. These features are discussed in order of their location relative to Truth or Consequences, from north to south and west to east. Although there are many faults in the region, those discussed here show evidence of Quatenary movement or are judged capable of generating large earthquakes (or moderate earthquakes nearby) that may affect the area.

\section{Winston Graben faults (1)}

The Winston graben, which is structurally well defined south of Dusty, N. Mex., is bounded by the Black Range to the west and south and the Sierra Cuchillo to the east. Although it is a prominent structural feature, little is known about the Quaternary stratigraphic or structural history of this rift basin. An unnamed, north-trending, east-dipping major normal fault forms the western margin of the Winston graben and the eastern flank of the Black Range. The geologic map of New Mexico (Dane and Bachman, 1965) shows this range-bounding fault as extending north of Dusty, but within Tertiary volcanics rocks of the range front. A detailed geologic map of the Winston area by Maxwell and Heyl (1976) shows Pennsylvanian, Permian, and Tertiary rock in the footwall of the fault and Tertiary rocks in the hanging wall, but only minor (and limited) displacement of Quaternary deposits. According to Coney (1976), most of the displacement on this fault occurred in the Miocene, between 20-6 $\mathrm{Ma}$.

The Gila Conglomerate ("Winston beds" in this area) is displaced along the length of this fault. These sediments, which are poorly dated but generally correlative to the Santa Fe Group, range from Miocene to Pliocene (or Pleistocene) in age. However, the lack to a detailed stratigraphic framework for the Gila in this region limits its use in constraining the time of late Cenozoic faulting. However, the presence of a prominent (though degraded) and rather straight escarpment along the eastern front of the $\mathrm{Black}$ 
Range, and the probability that the displaced, upper part of the Gila Conglomerate is late Pliocene or perhaps early Pleistocene in age, suggests that the fault was probably active in the past several million years.

Similar geomorphic and tectonic relations are seen along the eastern margin of the Winston graben, where a large-displacement normal fault forms the western flank of the Sierra Cuchillo. Geologic mapping in the Sierra Cuchillo (Jahns, 1955; Maxwell and Heyl, 1976; Jahns and others, 1978; Maldonado, 1980) has identified most of the Cenozoic faults, but their times of movement are poorly constrained or unknown. About $3 \mathrm{~km}$ northeast of Winston, 4.8-Ma basalt (Bachman and Mehnert, 1978) extends undisturbed across the southern part of the main range-front fault; this requires the latest movement at this point on the fault is no younger than earliest Pliocene. To the north, this fault forms the abrupt, eastward-curving front of the Sierra Cuchillo. The geomorphology along this part of the fault suggests Pliocene or younger movement, al though I have no morphometric or stratigraphic data to support this inference. There is a second major down-to-the-west fault about $3 \mathrm{~km}$ to the west and parallel to the front of the Sierra Cuchillo (Maxwell and Heyl, 1976). This fault, which is mainly in basin-fill deposits of the Winston graben, has a very subdued topographic expression and appears to have substantially less displacement than either of the range-bounding faults.

Normal faults along the east flank of the Sierra Cuchillo have the same general characteristics as the range-bounding faults of the winston graben. In fact, the structural depression between the Sierra Cuchillo and the southern part of the San Mateo Mountains (herein informally named the Monticello basin) has striking structural, depositional, and geomorphic similarities with the Winston graben, although it is not a structurally closed basin. The fault relations mentioned above support Chapin's (1978) conclusion that the Winston graben (and I infer the nearby Monticello basin) was formed during initial extension of the Rio Grande rift during the Miocene; since then, this arm of the rift has been largely abandoned as active extension shifted eastward to the central and eastern rift basins.

\section{Milligan Gulch fault zone (2)}

The Milligan Gulch fault zone is named here for a 25-km-long group of diffuse north-trending, intrabasin fault scarps in the west-central part of the San Marcial basin, northwest of the northern end of the Fra Cristobal Mountains (fig. 1). The fault zone is 45-70 km north of Truth or Consequences. Individual fault scarps range from 1 to $11 \mathrm{~km}$ in length, and are divided into two sets: the scarps north of Milligan Gulch, which generally face west; and the faults further south, which generally face east. The fault scarps in this zone are developed on middle Pleistocene gravel (Palomas Formation of Lozinsky and Hawley, 1986) that form the Cuchillo Plain, are commonly less than $5 \mathrm{~m}$ high, and are mature (highly degraded). The fault scarps are most apparent from the air or on aerial photographs. Scarps of the southern set face west (upslope) and have caused the alluvium of ephimeral streams to pond against the scarps. 
The extreme degradation of the scarps suggests that the Milligan Gulch fault zone was most recently active in middle to late(?) Pleistocene time (i.e., 100-200? ka ago). However, several scarps at the southeastern margin of the fault zone are formed on late(?) Pleistocene alluvium and appear fresher than the majority of the Milligan Gulch scarps. The latest movement on these young-appearing scarps probably occurred in the late Pleistocene.

There is a single fairly continuous, but isolated fault scarp that trends south and southeast in the southern part of the San Marcial basin, south of the Milligan Gulch fault zone. This scarp is named after Black Hill, a small but prominent hill just east of $\mathrm{N}$. Mex. State Highway 85 , about $4 \mathrm{~km}$ north of Nogal Canyon. One scarp profile from a fairly prominent scarp about $200 \mathrm{~m}$ east of the highway shows $4.3 \mathrm{~m}$ of surface of $f$ set of middle Pleistocene piedmont-slope alluvium. The maximum-slope angle $(\theta)$ of the scarp is only $6^{\circ}$ although the piedmont surface also slopes $1-2^{\circ}$ to the the same direction (northeast). This relation indicates only $4-5^{\circ}$ of divergence between the scarp and piedmont slope angles. For comparison, 5-m-high shorelines of Lake Bonneville (15 ka, fig. 3) have maximum slope angles of $18^{\circ}$ on nearly flat slopes and thus are 3 times as steep as the Black Hill scarp. The Black Hill scarp is morphologically similar to the Panguitch scarps of Bucknam and Anderson (1979) and Santa Rita scarps of Pearthree and Calvo (1987), both of which are considered to be about $100 \mathrm{ka}$. The Black Hill fault scarp probably formed in the early late $\mathrm{Pleistocene}$ (since $130 \mathrm{ka}$ ) rather than the latest Pleistocene $(35-10 \mathrm{ka})$. East of Interstate Highway 25, there are several scarps <5 $\mathrm{m}$ high on late(?) to middle Pleistocene alluvium: they mark the south end of the Milligan Gulch fault zone.

\section{Cuchillo Negro fault zone (3)}

The Cuchillo Negro fault zone (new name) occupies the central part of the Engle basin, about 15-20 km west and northwest of Truth or Consequences, N. Mex. (figs. 1 and 6 ). The zone is $30-\mathrm{km}$ long and $6-10 \mathrm{~km}$ wide; it consists mainly of north-northeast-trending, west-dipping normal faults that of Cuchillo surface, the middle Pleistocene constructional surface of the Palomas Formation of Lozinsky and Hawley, 1986. The scarps in this fault zone are topographically subdued and are generally less than $5 \mathrm{~m}$ high, with the exception of a prominent 10- to 15-m-high scarp in the central part of the fault zone. These scarps generally face upslope (to the west; fig. 6 ) and form a series of aligned catchment basins (dams). As such, the scarps do not degrade as described in the preceding section on "Fault Scarp Morphology." However, the general subdued nature of most of the scarps in the Cuchillo Negro fault zone (including the sparse east-facing ones) and the small amount of offset since middle Pleistocene time suggest the youngest movement occurred in late-middle to perhaps late Pleistocene time.

Intrabasin faults such as those of the Cuchillo Negro fault zone and the Milligan Gulch fault zone are probably subsidiary features which reflect extension across a broad band or series of step faults at depth, rather than extension along a discrete fault or narrow fault zone. Seager (1980, fig. 2) mapped similar intrabasin faults north of El Paso, Tex., and ascribed them to down warping of basin-fill sediments from localized extension along rangebounding faults on the west side of the Hueco basin. Many of the intrabasin faults of the rift may be shallow-seated features; however, some of the more continuous ones may penetrate deeply and be capable of large earthquakes 


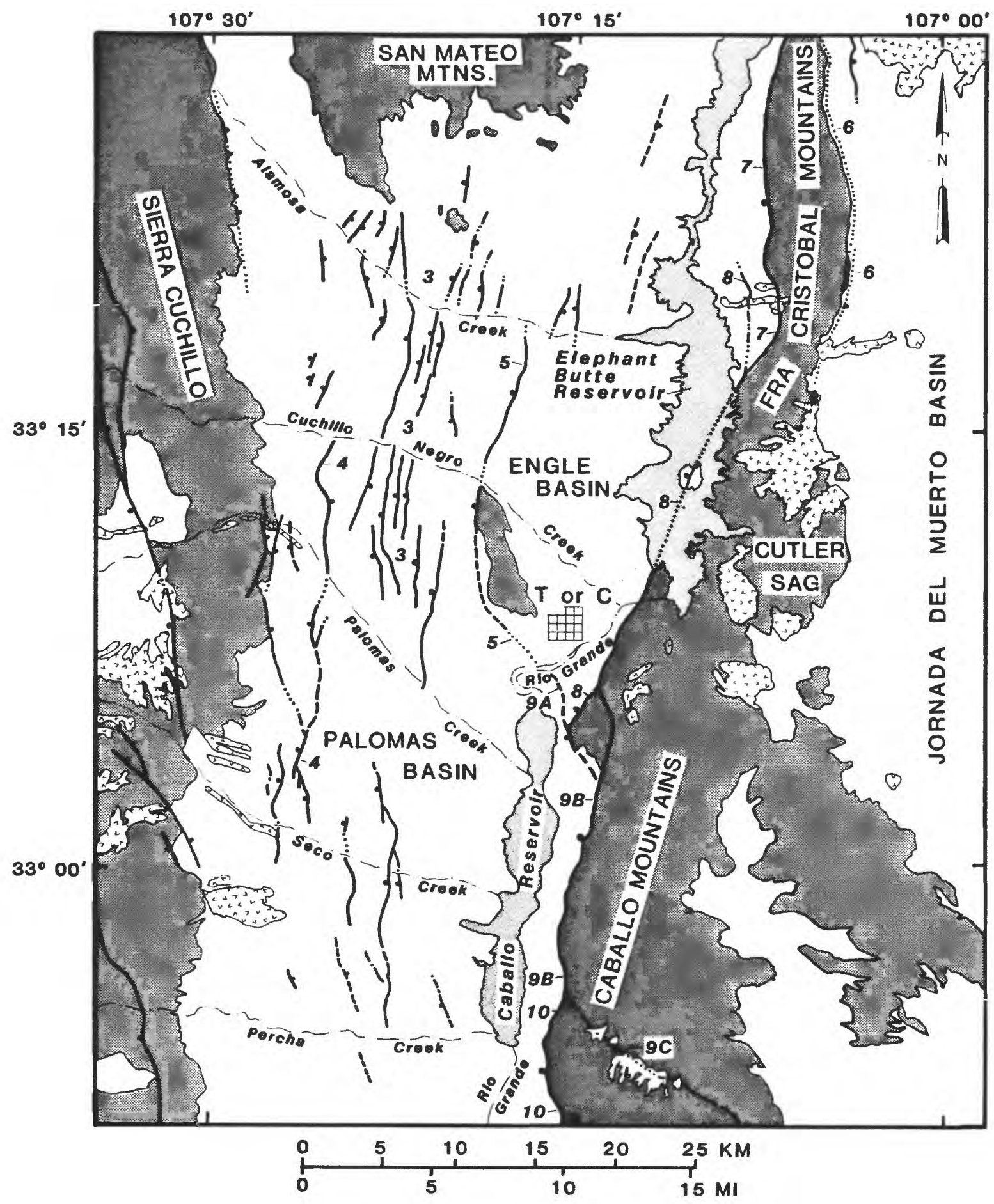

FIGURE 6. Map showing major Quaternary faults near Truth or Consequences, N. Mexico. Miocene and older rocks shown by dark stipple pattern; Pliocene and younger volcanic rocks shown by v-pattern, reservoirs shown by light stipple pattern. Heavy lines with ball on downdropped side are faults. Numbers refer to faults discussed in text. Caballo fault (9) is subdivided into A) north (Williamsbug), B) central, and C) south segments. 


\section{Palomas Creek rault (4)}

The Palomas Creek fault marks the southwestern edge of the Cuchillo Negro fault zone (3), about $16 \mathrm{~km}$ west of Truth or Consequences (fig. 1). North of Palomas Creek the fault forms a small, but continuous east-facing scarp on the Cuchillo surface (fig. 6). South of Palomas Creek, the scarp is less conspicuous as it crosses a dissected portion of the Cuchillo surface. From a point about $1.5 \mathrm{~km}$ south of Palomas Creek, south to Seco Creek, the fault forms a distinct, west-facing scarp $<5$ to $10 \mathrm{~m}$ in height. Sclssors-like movement is apparent along the $24-\mathrm{km}$ length of the fault; the throw is downto-the-east, north of Palomas Creek, and down-to-the-west, south of Palomas Creek. The Palomas Creek fault does not appear to extend south of Seco Creek, but there are three discrete fault scarps that continue to display down-tothe-west displacement further to the south.

The Palomas Creek fault cuts middle Pleistocene gravel shed from the Black Range to the west. The morphometric data from six profiles across the northern part of the Palomas Creek fault ( $f 1 \mathrm{~g} .7$ ) clearly show that the scarp is nearly in equilibrium with the surrounding piedmont. Scarps 1.9-3.5 $\mathrm{m}$ high have maximum scarp-slope angles of about 2-4० (to the east), whereas the piedmont slopes eastward at $3 / 4^{\circ}$ to $1.5^{\circ}$. For comparison, in Arizona Pearthree and Calvo (1987) report maximum scarp-slope angle of $4^{\circ}$ to $7^{\circ}$ on the 2- to 4-m-high Santa Rita scarps, which they considered to be about $100 \mathrm{ka}$. Thus, the Palomas Creek fault scarp appears to be similar to slightly more degraded than 100-ka scarps on similar materials and in a similar climate. These relations suggest that the Palomas Creek fault scarps are probably of late-middle Pleistocene age (130 ka to 250? ka).

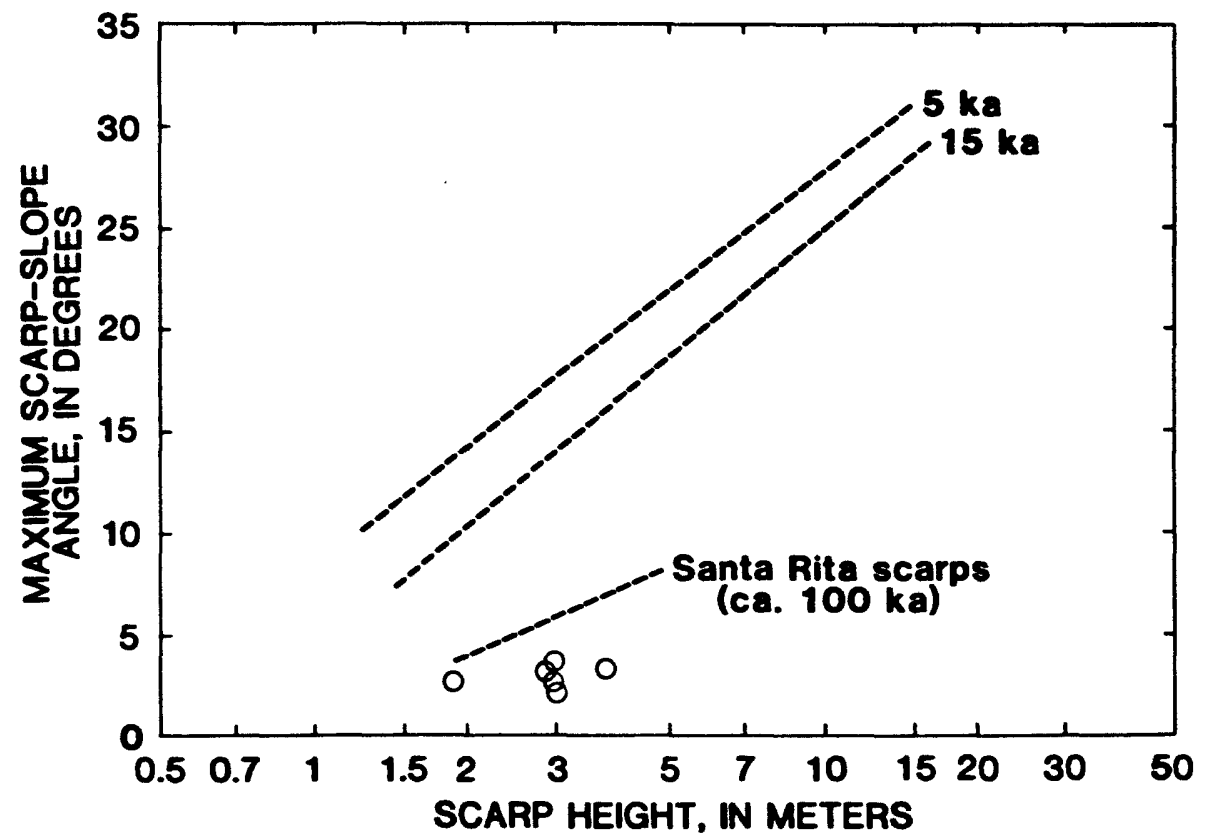

FIGURE 7.--Maximum scarp-slope angle $(\theta)$ plotted against total scarp helght (Hs, open circles) for the Palomas fault (4). The Palomas scarps are as old or older than the Santa Rita scarps of Pearthree and Calvo (1987). 


\section{Mud Springs fault (5)}

Kelley and Silver (1952) were the first to speculate about the existence of a major fault along the southwest and west flank of the Mud Springs Mountains, west of Truth or Consequences. My reconnaissance work suggests such a fault exists and that it has been active in late Quatenary time, at least along the northern part of its trace. The Mud Springs fault is considered to be the east-bounding fault of the Cuchillo Negro fault zone (3). The fault is marked by a 2- to 10-m-high scarp from Cuchillo Creek northward to Interstate Highway 25, northwest of Truth or Consequences (fig. 6). Along the west side of the Mud Springs Mountains, the fault does not have a noticeable surface trace, but may control a prominent north-south alignment of small ephimeral streams (this orientation is parallel to topographic contours rather than down gradient). South of Mud Mountain (near the southwest end of the Mud Springs Mountains), the trace of the fault turns southeast along Mud Springs Canyon where it offsets the piedmont facies of the Palomas Formation (Hawley and Seager, 1978, p. 87). Young movement along the canyon is probably masked by late Pleistocene and Holocene alluviation. However, the road cut west of Highway I-25, just south of Mud Springs Canyon, exposes piedmont-facies sediments that dip as much as $\mathrm{N}$. $7^{\circ}$ toward the inferred projection of the Mud Springs fault. Although its location is somewhat conjectural, the fault probably extends southeastward across the Rio Grande where it joins either 1) the Williamsburg fault--a northern segment of the Caballo fault (9), or 2) truncates the west fork of the Hot Springs fault (8) and joins the main, central segment of the Caballo fault (9). In either case, the Mud Springs fault seems to be one of several major structures that bound the large block that extends at and below the surface across the Rio Grande from the northern end of Caballo Reservoir to Truth or Consequences (Kelley and Silver, 1952; Hawley and Seager, 1978, p. 87-89). Lozinsky's (1987) eastwest cross section of the Palomas, Engle, and Jornada del Muerto Basins shows the Mud Springs fault as a major structure that bounds the buried Mud Springs high and separates relatively thick Santa Fe Group sediment in the Palomas Basin (on the west) from much thinner sediment in the Engle Basin (on the east). Although somewhat conjectural, Lozinsky's cross section (fig. 2) shows about $2,000 \mathrm{~m}$ of Tertiary throw on the Mud Springs fault.

The west-facing scarps of the Mud Springs fault are best preserved on the gently east-dipping Cuchillo Plain, northwest of Truth or Consequences, where they have ponded alluvium or diverted streams to the north or south. As is the case of the Cuchillo Negro fault zone (3), the degraded nature of the fault scarps and the age of the displaced Cuchillo surface suggest that the latest movement on this part of the Mud Springs fault occurred in the latemiddle Pleistocene.

\section{Fra Cristobal fault (6)}

The Fra Cristobal fault extends $25 \mathrm{~km}$ across the piedmont slope at the eastern base of the Fra Cristobal Mountains (Thompson, 1955, 1978; McCleary, 1960; Nelson, 1986). These mountains form the western edge of the central part of the Jornada del Muerto basin. Although a fairly steep escarpment is present along the range front, there is no evidence of Quaternary faulting along the suspected trace of the fault (figs. 1 and 6). At its southern terminus about $6 \mathrm{~km}$ northeast of Kettle Top Butte, the Fra Cristobal fault is buried by a Pliocene or Pleistocene(?) basalt flow. 
Several vents and cones are aligned with the southward projection of the fault, suggesting a spatial relation between extrusion of the basalts and early movement on the fault. Although this basalt is undated, flows at similar topographic levels in this area are generally 2-3 Ma (Bachman and Mehnert, 1978), so it seems likely that the most-recent movement along this part of the fault must be Pliocene rather than the Pleistocene. Just east of the north end of the Fra Cristobal Mountains there is an inconspicuous scarp having minor displacement in late(?) to middle Pleistocene alluvium. The fault, which may be an en echelon splay of the Fra Cristobal fault, either dies out north of the Fra Cristobal Mountains or is covered by basalt flows, one of which was determined to be $0.76 \mathrm{Ma}$ by Bachman and Mehnert (1978).

\section{Walnut Canyon fault (7)}

The Walnut Canyon fault of Warren (1978) forms the western edge of the Fra Cristobal Mountains and the eastern margin of the central (axial) Rio Grande graben in the Engle basin (figs. 1 and 6). The south end of the fault appears to merge with or terminate against the Hot Springs fault (8) of Kelley and Silver (1952) and Thompson (1955, 1978) about $6 \mathrm{~km}$ north of Kettle Top Butte. As described above, the Walnut Canyon fault is $24 \mathrm{~km} l o n g$.

The Walnut Canyon fault also has been called the "Hot Springs fault" by Thompson (1955, 1978), and the "West Vein fault" by Van Allen and others (1984) in their discussion of fluorite deposits associated with the fault. However, I prefer to use the separate term Wal nut Canyon because the fault seems to have significant? y more Cenozoic displacement than does the Hot Springs fault just to the south.

No fault scarps were found on Quaternary deposits along the western front of the Fra Cristobal Mountains although there has been ample opportunity to preserve such features if they had formed. However, Nelson (1986, p. 90) reports of $f$ set alluvial fans (of unknown age) near the north end of the range. The trace of the fault is commonly marked by a wall-like escarpment formed by silicified fault breccia (Jacobs, 1956; Thompson, 1978; Van Allen and others, 1984); this feature is well preserved along most of the mountain front. I found no evidence that middle or late Pleistocene alluvium, which locally buries the silicified zone, is of fset; so I infer that the latest movement on the Walnut Canyon fault probably occurred in Pliocene or early Pleistocene time.

\section{Hot Springs fault (8)}

The Hot Springs fault was first described in detail by Kelley and Silver (1952) as the major fault bounding the west margin of the northern Caballo Mountains and the southeast edge of the Engle basin. In this area the fault separates a strongly upl if ted and east-tilted block of Precambrian through Cretaceous rocks from a north-tilted and downdropped block of Precambrian to Permian bedrock and Santa Fe Group sediments. Lozinsky (1986) suggests that some of the apparent motion on the southern part of the Hot Springs fault is the result of right-lateral strike slip movement related to Laramide compression, rather than to Cenozoic extension. About $3 \mathrm{~km}$ south of Truth or Consequences, the Hot Springs fault forks, with the eastern fork striking south and southeast (fig. 6). The two faults bound a large block of Precambrian rock, which has been downdropped an unknown amount. There has not 
been enough vertical throw across the eastern fork to downdrop and preserve Paleozoic rocks that are exposed in the adjacent, upper flank of the Caballo Mountains. The western fork of the Hot Springs fault seems to be truncated on the south by the Williamsburg segment of the the Caballo fault (9), thereby isolating the block of Precambrian rock from a surrounding mass of Tertiary sediments. From this block south, the extension of the range-bounding Hot Springs fault (eastern fork) is known as Caballo fault (9, fig. 6) and is mainly exposed in basin-fill and surficial deposits.

The northern terminus of the Hot Springs fault is somewhat enigmatic; the fault either continues as an inactive, buried structure along the west flank of the Fra Cristobal Mountains for an additional $25 \mathrm{~km}$ as interpreted by Thompson (1955, 1978) or turns to the north at its junction with the walnut Canyon fault ( $7 ; 6 \mathrm{~km}$ north of Kettle Top Butte) and dies out beneath Elephant Butte Reservoir (Warren, 1978). I favor the latter interpretation and thus consider Warren's Walnut Canyon fault (7) as the bounding structure along the west flank of the Fra Cristobal Mountains.

Sediments in the upper part of the Santa Fe Group (Palomas Formation of Lozinsky, 1986) are downfaulted along the Hot Springs fault both southeast of Truth or Consequences (Hawley and Seager, 1978; Lozinsky, 1986) and west of the central Fra Cristobal Mountains. These relations indicate movement on the Hot Springs fault during or since the Pliocene. Basalts along the Hot Springs fault help constrain the timing of its early movement. For example, Lozinsky and others (1986, p. 65) reviews evidence that $2.5 \mathrm{Ma}$ or slightly older basaltic maar deposits exposed on Rattlesnake Island of Elephant Butte Reservoir have not been offset by the fault. Farther north, Warren (1978) determined that there $90 \mathrm{~m}$ or less of displacement of "Quaternary" basalts along the Hot Springs fault near Black Bluffs; these rocks may actually be late Pliocene, because similar basalt flows $9 \mathrm{~km}$ northwest near Mitchell Point and a basalt cinder cone $16 \mathrm{~km}$ to the southeast have been $\mathrm{K}$-Ar dated by Bachman and Mehnert (1978) at 2.9 and $2.1 \mathrm{Ma}$, respectively. If an age range of 2-3 $\mathrm{Ma}$ is used for the faulted basalts mapped by Warren, then the average vertical slip rate for the northern part of the fault is a relatively low 30$45 \mathrm{~m} / \mathrm{Ma}(0.03-0.45 \mathrm{~mm} / \mathrm{yr})$. No Quaternary fault scarps have been recognized along the Hot Springs fault and Lozinsky (1986) found no evidence of faulting in deposits younger than the Palomas Formation (Pliocene to middle Pleistocene). However, on the northwest flank of the northern Caballo Mountains there are steep, 50-150-m-high bedrock escarpments at several places along the fault. It appears that the last demonstrable movement on the Hot Springs fault is Pliocene or possibly early Pleistocene.

\section{Caballo fault (9)}

The Caballo fault forms a prominent escarpment along the western base of the central Caballo Mountains and a subdued escarpment to the southeast through the southern Caballo Mountains. Its north end is marked by the Williamsburg fault scarps, which cross a broad piedmont slope underlain by Tortugas alluvium (L.L. Foley, written commun., 1987). This portion of the fault may connect with a southeasterly projection of the Mud Springs fault (5), which crosses the Rio Grande from the northwest, and the western fork of the Hot Springs fault (8) near Red Canyon--due east of the northern end of the Caballo Reservoir (fig. 6). The southern end of the Caballo fault is less well defined because the fault seems to decreas in throw to the southeast. 
Seager and others (1982) show the Caballo fault extending to the north end of the Hogue Hills (22 km north of Hatch, N. Mex.), for a total length of $29 \mathrm{~km}$ along trace.

The general strike of the fault is southerly for $16 \mathrm{~km}$ along the central Caballos, but changes to southeasterly at Flordillo Canyon, $4.5 \mathrm{~km}$ northeast of the abutment of Caballo Reservoir. The southern 13-km-long segment of the Caballo fault $(13 \mathrm{~km})$ forms the structural boundary between the southern part of the Caballo Mountains block and the foundered Red Hills block and accompanying Apache Valley, which in turn are bounded on the west by the Red Hills fault (10) and the axial graben of the rift.

The Caballo fault dips $70-90^{\circ}$ to the west and has a stratigraphic throw that ranges from about $600 \mathrm{~m}$ at its juction with the Hot Springs fault to 1500-3000 m near Timber Mountain in the central Caballo Mountains (Kelley and Silver, 1952). The throw diminishes to the south along the southern part of the fault, where Tertiary and Pennsylvanian rock are in fault contact (Seager and others, 1982). Where the fault has placed basin-fill or surficial deposits against bedrock, the fault is clearly marked by what Kelley and Silver (1952) refer to as a "fan scarp" as much as $20 \mathrm{~m}$ in height. Fault scarps on middle Pleistocene piedmont-slope deposits of the Palomas are as much as 40-50 $\mathrm{m}$ high, and obviously are the product of repeated faulting in late Quaternary time.

The Williamsburg fault, northwest of the main range-bounding trace of the Caballo fault, cuts middle and late Pleistocene alluvium and Holocene(?) eolian sand. The Williamsburg fault was named by L.L Foley for the small town north of the fault and is considered here as the basinward, northern segment of the Caballo fault: as such it is discussed here with the Caballo fault.

Several profiles were measured across scarps of the Williamsburg fault (fig. 8) by L.L. Foley prior to excavation of an exploratory trench in June 1987. Foley's trenching study revealed two discrete episodes of movement in Tortugas alluvium (ca. 250? ka), the youngest of which cuts Holocene eolian sand. Her scarp profiles suggest about 5-6 $\mathrm{m}$ of displacement of the surfaces above and below the scarp, although an extensive blanket of eolian sand is embanked against and buries part of the west- (windward-) facing scarp. Interpretation of the morphometric data is complicated by the deposition of the eolian sand, which tends to reduce the scarp height dramatically. Nevertheless, the plot of $\theta$ versus $\mathrm{Hm}$ or $\mathrm{Ht}$ reveal a fairly young, but compound morphology. Most of the data plot between the 5 and $15 \mathrm{ka}$ calibration ines ( $\mathrm{fig} .12$ ), and data for the youngest element of displacement (i.e., Hs; table 1) plot well above the $5 \mathrm{ka}$ line, suggesting that the most recent movement on this segment of the Caballo fault is late Holocene $(<5 \mathrm{ka})$.

Scarp profiles along the central segment of the Caballo fault were collected independently by L.L. Foley and myself (see table 1). The profiles span $11 \mathrm{~km}$ of the fault and were collected at sites that were judged to be geomorphically stable. The sites are clustered in 6 areas, which from north to south are named Section 10, Ash Spring North, Ash Spring South, Wild Horse Canyon, Granite Canyon South, and Floridillo Canyon for the nearest prominent geographic feature. The two profiles at the Section 10 site are shown on figure 9, whereas the remaining 5 sites are shown on figures 10 and 11 . 


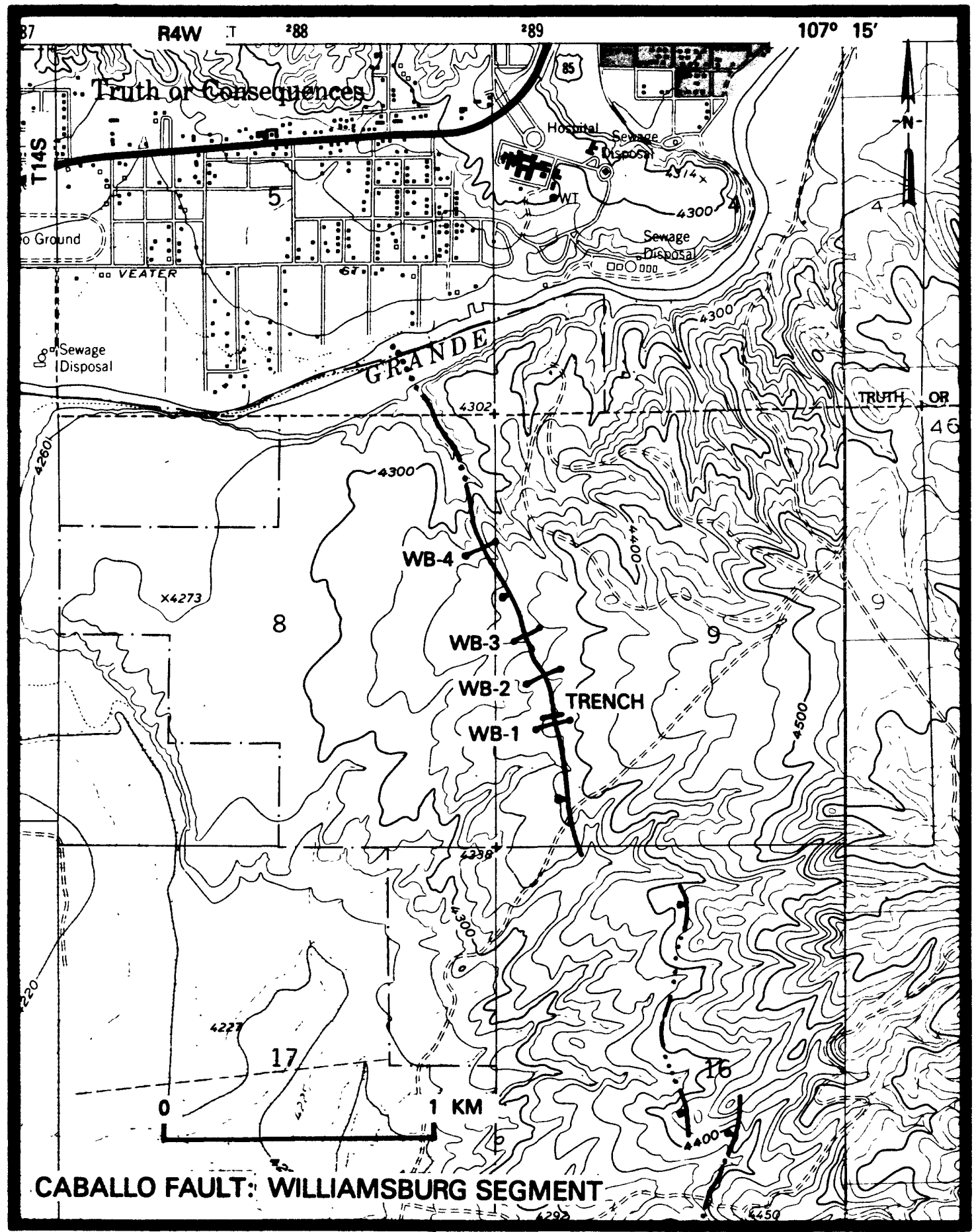

FIGURE 8.--Map showing location of profiles and trench along the Williamsburg fault scarp. Area includes northeast part of the Williamsburg and northwest part of the Palomas Gap 7.5-minute quadrangles, New Mexico. 


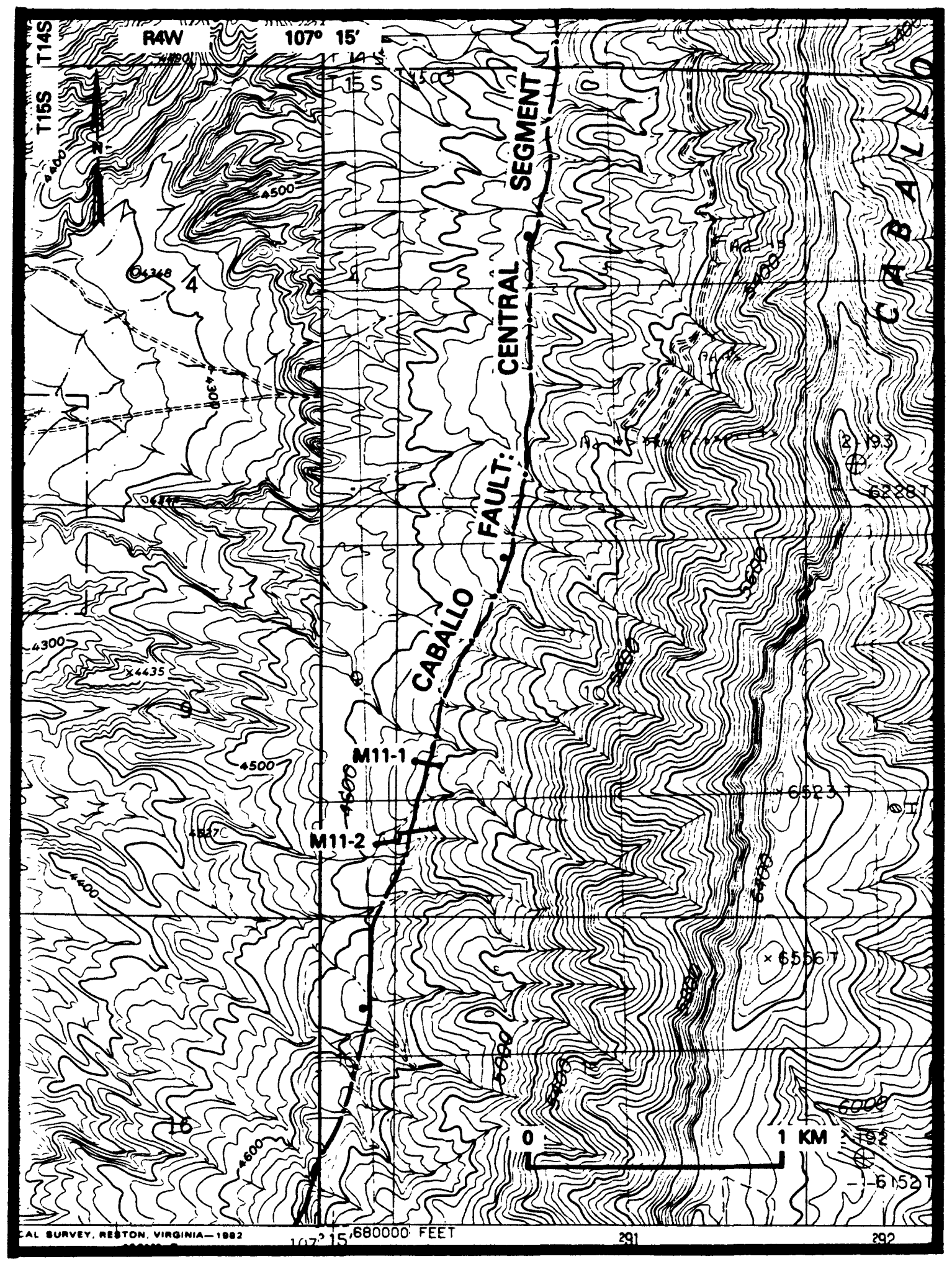

FICURE 9.--Map showing location of profiles along the Caballo fault and the Section 10 site. Area includes the southeast part of the Williamsburg and southwest part of the Palomas Gap 7.5-minute quadrangles, New Mexico. 


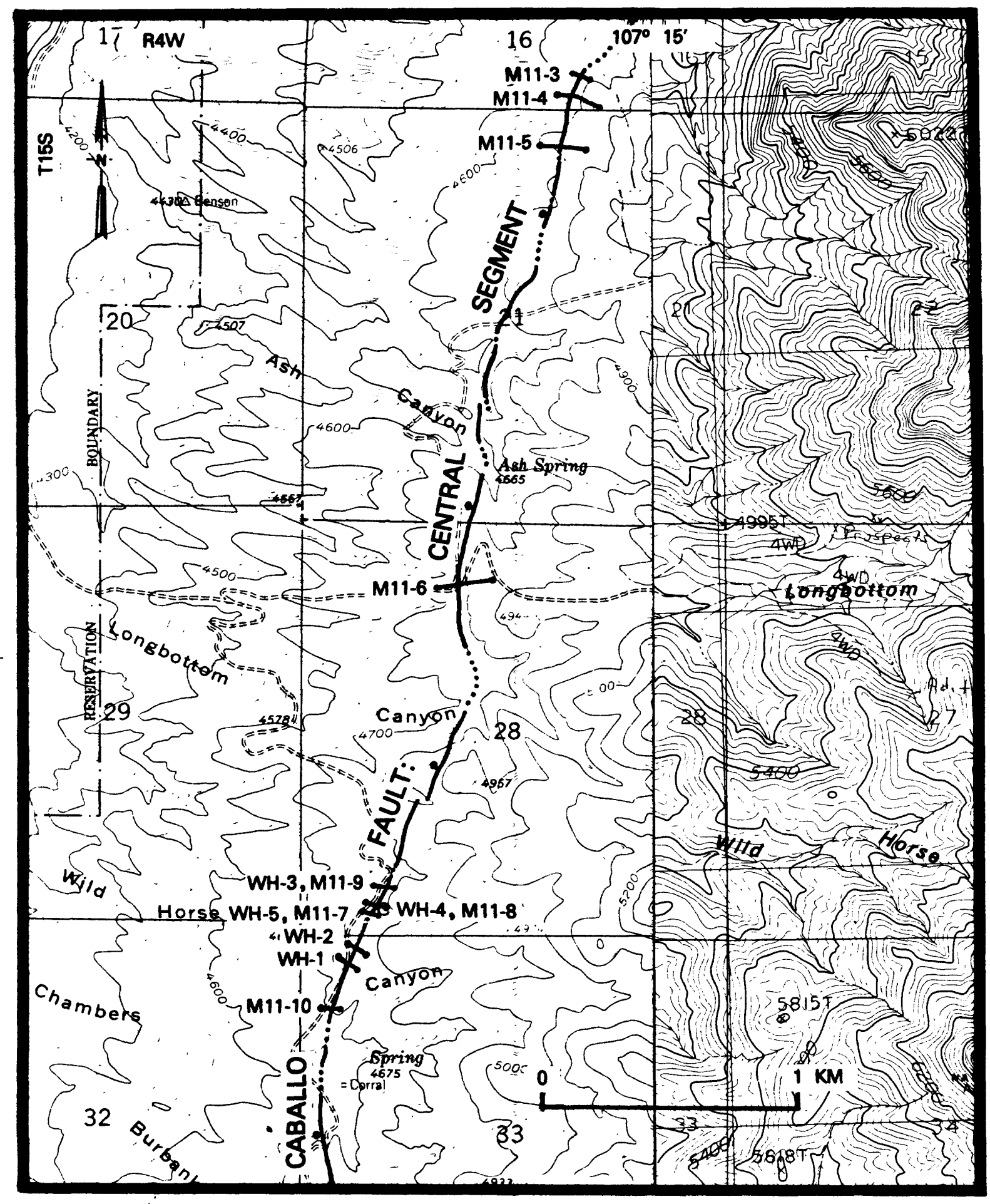

FIGURE 10.--Map showing location of scarp profiles along the Caballo fault near Ash Springs and Wild Horse Canyon. Area includes northeast part of the Caballo and the northwest part of the Apache Gap 7.5-minutes quadrangles, New Mexico. 


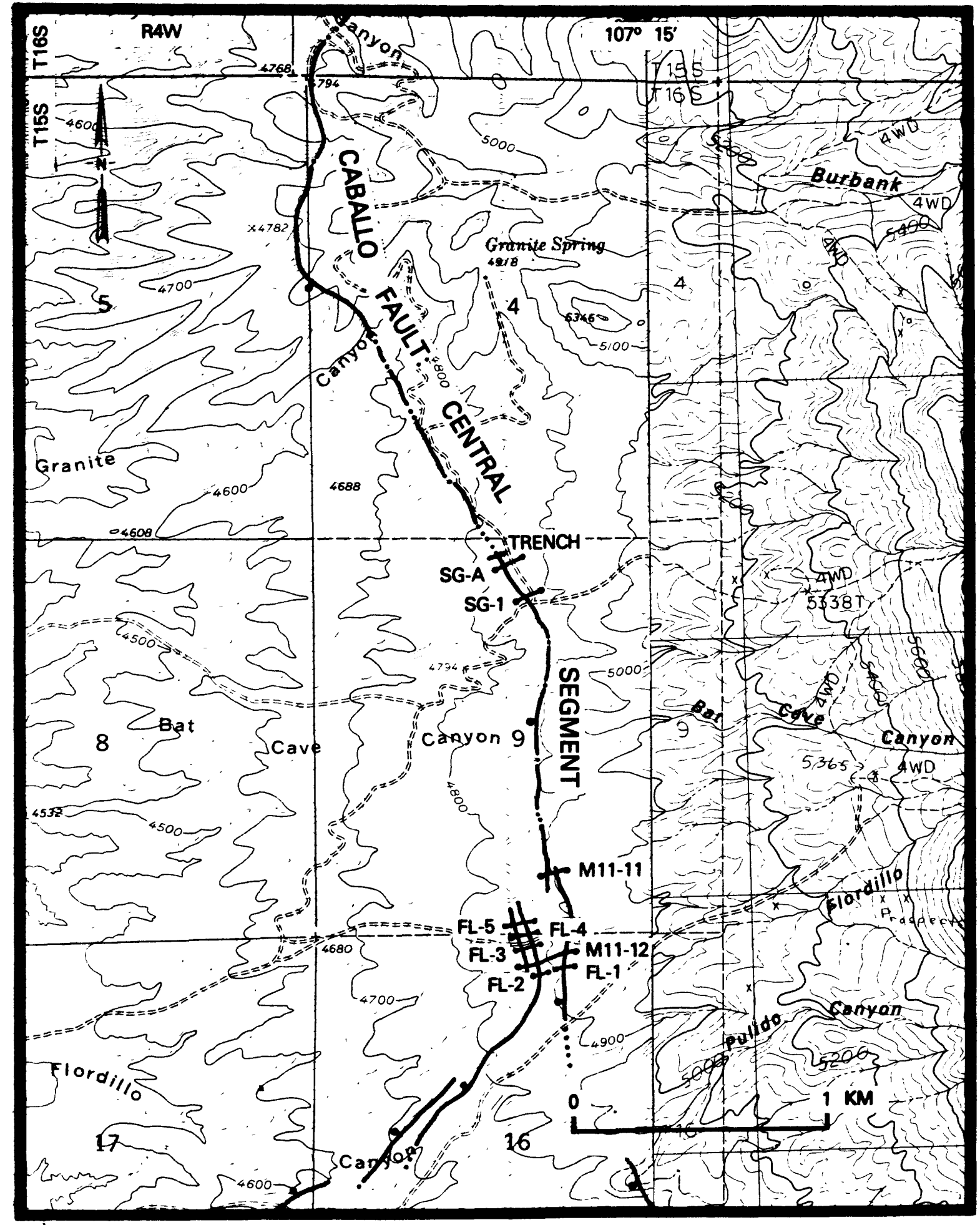

FIGURE 11.--Map showing location of scarp profiles and trench along the Caballo fault between Granite and Flordillo Canyons. Area includes the east part of the Caballo and the west part of the Apache Gap 7.5-minute quadrangles, New Mexico. 
Most of the scarp profiles were measured on alluvial units thought to be 125-250 ka old (the Picacho and Tortugas alluvium), although some of the largest ones (27-43 $\mathrm{m}$ high) are on the constructional surface of the piedmont facies of the Palomas Formation. Scarps on post-Picacho alluvium are hard to find, inasmuch as the Caballo fault is high on the piedmont slope where these units tend to be entrenched in narrow channels on the piedmont. Farther downstream, toward Caballo Reservoir, the late Pleistocene and Holocene alluvium spread out in wide channels to form terraces and alluvial fans.

The morphometric data shown on figures 12 and 13 include 30 profiles from the central segment of the Caballo fault and 4 profiles from the Williamsburg scarps (northern segment of the Caballo fault). The data based on total scarp height (Ht) form a large envelope that plots between the 5 and $15 \mathrm{ka}$ calibration lines, albeit with an anonymously low slope (table 1, b value 12.2 versus 21.0 for the $15 \mathrm{ka} l$ ine). The low slope is driven by three large scarp height values $(27-43 \mathrm{~m}$, fig. 12), which skew the right-hand part of the data set. If one disregards these data, the values would be centered between the two control I ines (compare with fig. 13). However, because the data are known to be from compound scarps formed during two or more discrete surfacerupturing events, their heights (table 1) reflect the cumulative movement since deposition of the faulted alluvium, whereas the maximum slope angle $(\theta)$ is controlled by the recent movement (scarp-forming event) on the fault. The net result is scarp morphologies that appear too old for the youngest event.

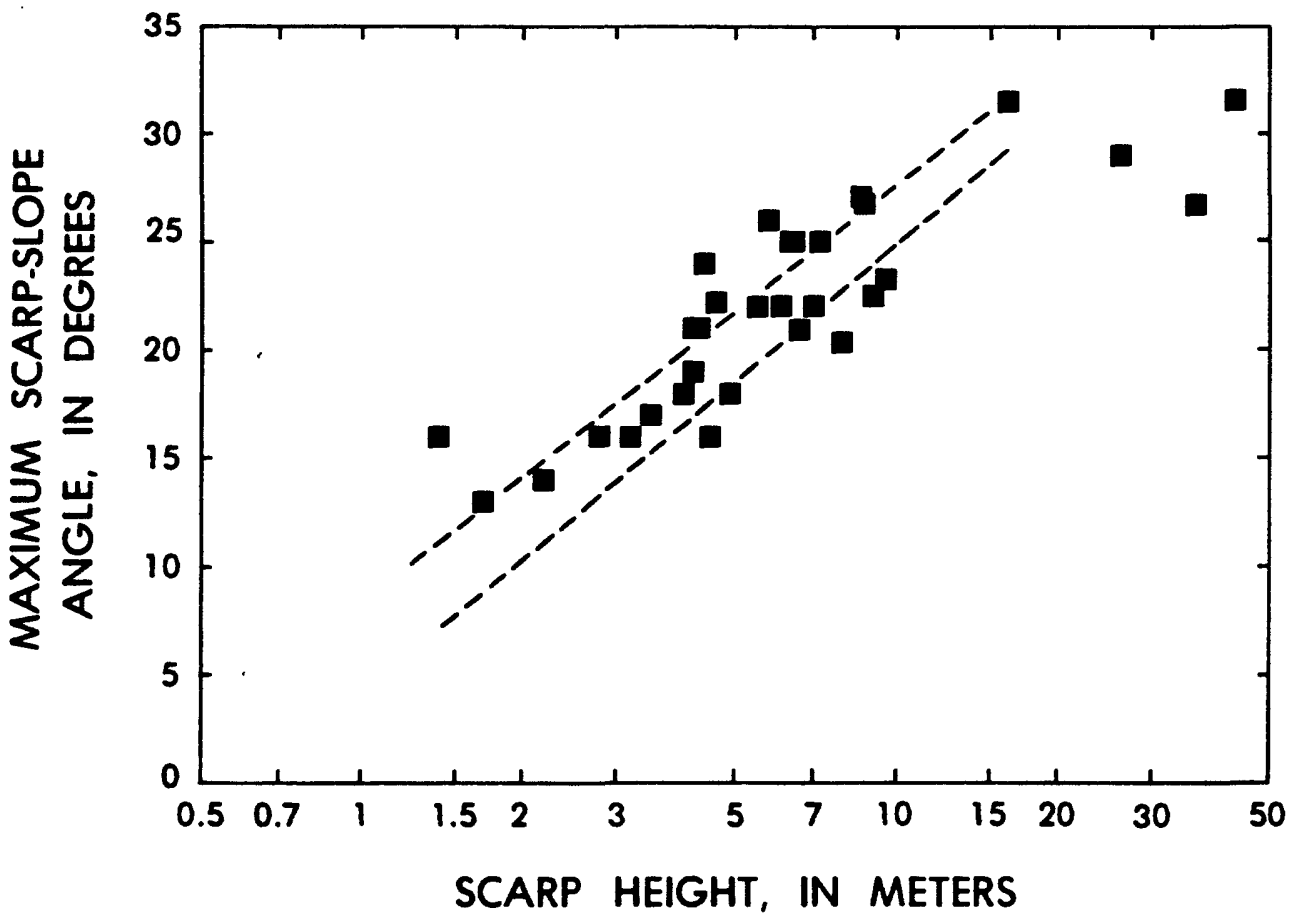

FIGURE 12.--Maximum scarp-slope angle $(\theta)$ plotted against total scarp height (Ht, filled squares) for the Caballo fault (9) See table 1 for morphometric data and figures 8-11 for location of profiles. 


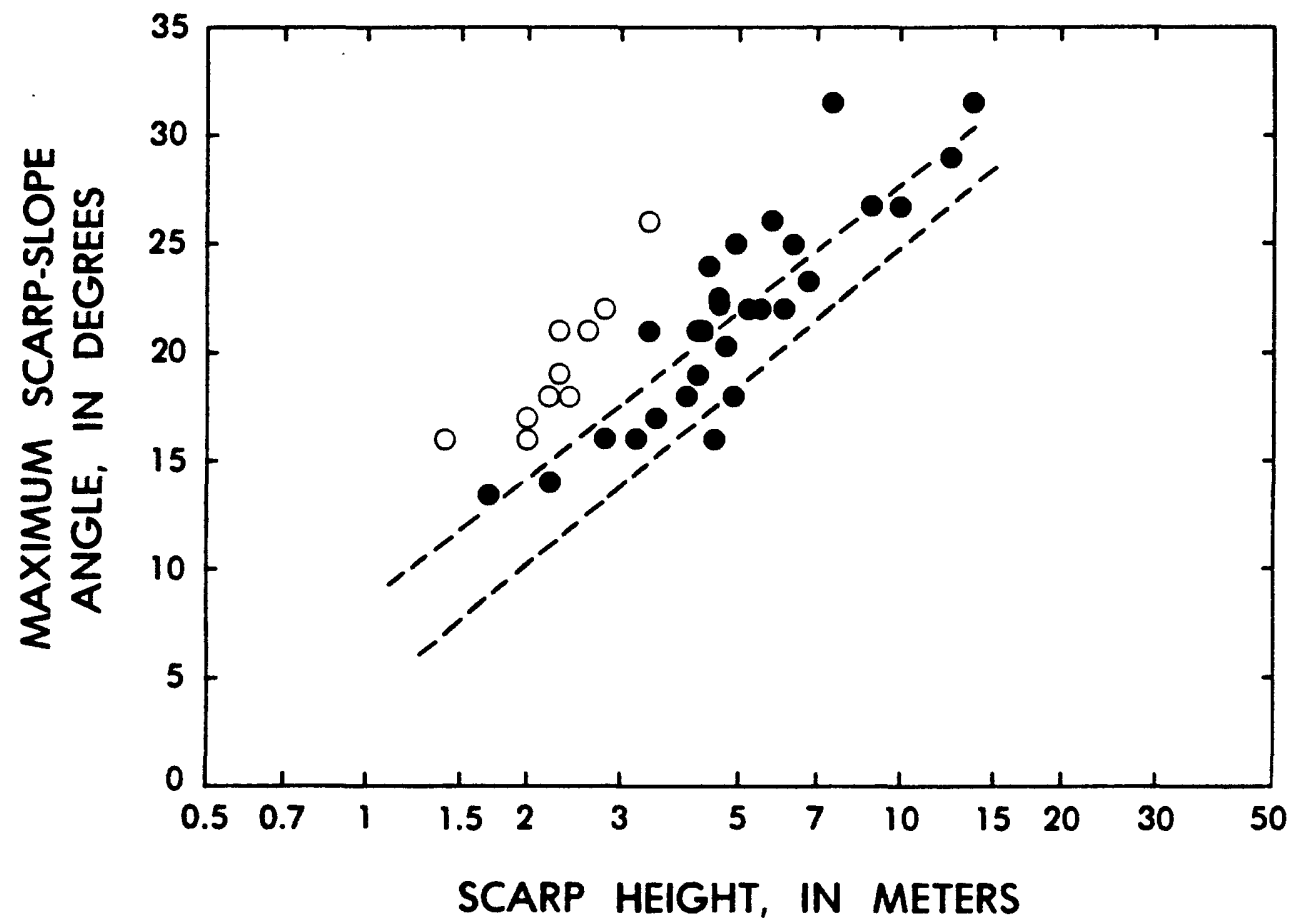

FIGURE 13.--Maximum scarp-slope angle $(\theta)$ plotted against heights (Hs, open circles; $\mathrm{Hm}$, filled circles) for all scarp profiles along the Caballo fault (9). See figures 8-11 for location of scarp profiles.

Some of the scarp profiles have bevels (compound slope angles) that suggest a younger element of scarp height related to the present maximum slope angle (table 1). Figure 13 shows these data (Hs) in comparison to data for multiple-event ( $\mathrm{Hm}$ ) scarps, which are the result of 2 or 3 events (scarp heights of $(12-15 \mathrm{~m})$. These data suggest that the youngest element of the scarps formed since $5 \mathrm{ka}$ (data plot above the $5 \mathrm{ka} l$ ine) and as such give the multiple-event scarps a Holocene appearance (25 of $27 \mathrm{Hm}$ data plot above the $15 \mathrm{ka}$ line and the regression equation for $\theta$ versus $\mathrm{Hm}$ is between the 5 and 15 ka control lines; table 1). The timing of the second (older) surfacerupturing event along the Caballo event is hard to determine, since the younger event has profoundly modified the preexisting fault scarps. Evidence from L.L. Foley's trenches across the central and northern (Williamsburg) segments of the Caballo fault clearly demonstrate an older event; however, it may be close to the Picacho alluvium in age (100-150 ka) at the northern end. If the second event is this old along the central segment, one would expect to see more pronounced and abundant evidence of compound scarps. 
The scarp morphology data (figs. 12 and 13) and relations of scarp height to surficial geologic units along the central and northern segments of the Caballo fault (table 1) suggest multiple episodes of movement from the middle Pleistocene to Holocene, the youngest of which is probably late Holocene $(<5 \mathrm{ka})$. Sparse evidence from compound scarps suggests that there was at least one prior faulting event since the deposition of the Tortugas and perhaps the Picacho alluvium. These relations leads me to speculate that the Caballo fault has fairly long recurrence intervals, in the range of $100 \mathrm{ka}$. If true, the average slip rates for the Caballo fault must be $10 \mathrm{ow}$, on the order of $0.02-0.03 \mathrm{~mm} / \mathrm{yr}(5-8 \mathrm{~m}$ of of fset in $250 \mathrm{ka})$. If one uses an age of about $500-$ $600 \mathrm{ka}$ for the constructional surface of the Palomas Formation, and 30-40 m of net of fset (scarps are $27-43 \mathrm{~m}$ high), the resulting long-term slip rate is $0.05-0.08 \mathrm{~mm} / \mathrm{yr}$, or about twice the late Quaternary slip rate cited above. These slip rates and recurrence intervals are substantially lower and longer than observed on an adjacent rift structure to the east; the San Andres-OrganEast Franklin Mountains fault zone of the Tularosa-Hueco basin.

The southern segment of the Caballo fault has no evidence of movement since the end of deposition of the Palomas Formation (middle Quaternary time). Mapping by Seager and others (1982) shows no faults in surficial deposits which overlie the fault as mapped. It appears that this segment of the fault, which must have been active in Pliocene and early Pleistocene time, has become quiescent, perhaps as active extension moved basinward toward or onto the Red Hills fault (10).

\section{Red Hills Fault (10)}

The Red Hills fault is a western en echelon splay of the Caballo fault; it bounds the west edge of the Red Hills which is a foundered block of bedrock stranded at an intermediate structural level between the uplifted Caballo Mountains and the deep Palomas basin of the Rio Grande rift (fig. 1).

Scarps of the central segment of the Caballo fault feather out at its southern end, with minor and discontinuous surface ruptures continuing about 1 $\mathrm{km}$ south toward the southern segment. However, the most continuous ruptures turn south-southwest at the south end of the central segment, and extend along or subparallel to drainage lines $1.5 \mathrm{~km}$ past Flordillo Canyon to near the northwest end of the Red Hills, where the fault again turns southward.

Mapping of Seager and others (1982) shows the Red Hills fault almost entirely at the base of bedrock along the west edge of the Red Hills. Reconnaissance by L.L Foley (oral commun., 1987) suggests that the fault is marked by sparse scarps that are cored by bedrock. However, little can be done with the morphology of these scarps inasmuch as they erode significantly slower than scarps on alluvium. Nevertheless, the presence of scarps along the Red Hills suggest some faulting in the Quaternary. Sediment of the Camp Rice and Palomas Formations have been deposited against the Red Hills along most of trace of the Red Hills fault, which demonstrates that the fault was probably an active range-bounding structure in the Pliocene to middle Pleistocene.

I suspect there has been little or no significant movement on the Red Hills fault in the late Pleistocene or Holocene. This inference is based on the lack of scarps in fan-head alluvium at the mouths of arroyos that cross the fault. However, there has been more Quaternary movement on the Red Hills 
fault than on the southern segment of the Caballo fault, which lies to directly to the east. Perhaps movement has been abandoned on the souther $n$ part of the Caballo fault in favor of the Red Hills fault as extension in the rift becomes concentrated on basinward faults of the rift. This scenario is identical to that proposed for the Hot Springs fault along the northern Caballo Mountains.

\section{San Andres-Organ-East Franklin Mountains fault system (11)}

The San Andres-Organ-East Franklin Mountains fault system of Seager (1981) trends roughly north-south along the three major mountain ranges that bound the west edge of the Tularosa and Hueco Basins ( $f$ ig. 1). When considered together, this system (or zone) of faults has a straight-line length of about $182 \mathrm{~km}$ : this length, and the it's history of repeated and relatively recent movement, make it the most impressive Quaternary fault zones in the interior of the United States. For comparison, the Wasatch fault zone of Utah and southern Idaho is $335 \mathrm{~km}$ long (length along trace is $370 \mathrm{~km}$ ) and has 10-12 discrete fault segments that act independently of one another (Machette and others, 1986b, 1987).

Although this fault system is no closer than $60 \mathrm{~km}$ east of Truth or Consequences, a brief summary of the fault system is included here because it shows evidence of young (Holocene) movement and relatively short recurrence intervals compared with other major faults in the southern Rio Grande rift. A major earthquake (i.e., moment magnitude $>7$ ) along this fault system may generate significant ground shaking in the Truth or Consequences area, especially in areas susceptible to liquifaction or with thick sedimentary fill.

Until recently, little modern or detailed work has been done on the fault system, partly because most of their surface ruptures are within a restricted military zone comprised of the White Sands Missile Range (WSMR), Fort Bliss Military Reservation, and MacGregor Bombing Range. Machette's (1987b) reconnaissance studies of these faults indicates that they have been recurrently active for at least the past $0.5 \mathrm{Ma}$. Although late Pleistocene or Holocene movement occurred on all fault segments of the system, the most recent movement (middle and late Holocene) has been on the Organ Mountains fault.

Evidence for different times of movement along parts of the fault system, coupled with its extraordinary length $(182 \mathrm{~km})$, demands that the fault system has discrete faults and fault segments which rupture independently of one another. The faults and fault segments suggested by Machette (1987b) are between 36 and $57 \mathrm{~km}$ in length, except the 22-km long northern segment of the San Andres Mountain fault which is markedly less active than the other segments. These fault segments have evidence of about $2 \mathrm{~m}$ of displacement per surface faulting event and are comparable with historic surface faulting associated with earthquakes of moment magnitude 7.0-7.5 in the Basin and Range province of the Western U.S.

Morphologic, pedologic (soils), and geologic data collected along the fault system show that all the faults and their segments were active during the late Pleistocene ( 130 to $10 \mathrm{ka}$ ) or latest Pleistocene (35 to $10 \mathrm{ka}$ ), and three faults and segments were probably active in the Holocene (less than $10 \mathrm{ka})$. Those most recently active are the southern segment of the San Andres 
fault, the Organ Mountains fault, and the East Franklin Mountains fault (fig. 1). Data from the Cox Ranch site on the Organ Mountains fault suggest two discrete movements in the past $5 \mathrm{ka}$ (Gile, 1987; Machette, 1987b) making it the most active of the Quaternary faults in southern Rio Grande rift. The Cox Ranch site is immediately west of White Sands, New Mexico--the headquarters for WSMR. In addition to these faults, the central and northern segments of San Andres fault are suspected of having 1 atest Pleistocene and late Pleistocene movement, respectively.

The average recurrence interval for 1 arge-magnitude earthquakes along the San Andres-Organ-East Franklin Mountains fault system is probably about 2,500 yr, as determined from evidence of four surface rupturing events (on two faults and a separate fault segment) during the past 10,000 yr (Holocene). Recurrence intervals for surface ruptures on individual faults ranges from 4,000-5,000 yr on the Organ Mountains fault to 20,000 yr on the southern and central segments of the San Andres Mountains fault.

\section{SUMMARY}

Evidence of Quaternary faulting is abundant in the southern part of the Rio Grande rift of south-central New Mexico. In the vicinity of Truth or Consequences, both intrabasin and major range-bounding faults displace Pliocene to early(?) Pleistocene basin-fill deposits and middle to latest Pleistocene and (less commonly) Holocene surficial deposits. Morphologic, pedologic (soil), and geologic data collected along the major faults near Truth or Consequences, $N$. Mex., show that several were active during the late $(130-10 \mathrm{ka})$ or latest $(35-10 \mathrm{ka})$ Pleistocene. Two segments of the Caballo fault as well as much of the San Andres-Organ-East Franklin Mountains fault system have been active in the Holocene (less than $10 \mathrm{ka}$ ).

The Caballo fault and San Andres-Organ-East Franklin Mountains fault system show evidence of discrete segmentation (from comparisons of scarpmorphology data and geometric pattern) and recurrent movement. The lengths of these faults and fault segments range from $16 \mathrm{~km}$ for the central segment of Caballo fault to $36-57 \mathrm{~km}$ for the San Andres-Organ-East Frankl in Mountains fault system. These lengths of faulting, coupled with evidence of about $2 \mathrm{~m}$ displacement per surface-faulting events (see Hs values, table 1; Machette 1987b) are compatible with earthquakes of moment magnitude 7.0-7.5 as seen historically in the Basin and Range province (Machette and others, 1987c). The average recurrence interval for large-magnitude earthquakes along the Caballo fault appears to be long (100? ka) as determined from evidence of 2 surface-rupturing events during the past 250? ka. Shorter recurrence intervals (commonly 5-20 ka) occur on the San Andres-Organ-East Frankl in Mountains fault system, but this fault system is no closer than $60 \mathrm{~km}$ from Truth or Consequences.

Fault scarps $25-50 \mathrm{~m}$ high are preserved on middle to upper Pleistocene surficial deposits along the Caballo fault. Scarps this high result from recurrent faulting, as evidenced by decreasing amounts of of $f$ set in progressively younger deposits. Some of the apparent relief on these scarps (or fault-line scarps) may result from erosion, whereas as much as half of the of fset on the fault may be masked by young deposits that accumulate at the toe of a fault scarp. Thus, the scarp heights and long-term slip rates recorded here may not accurately reflect the true amount of movement on the fault. 
Intrabasin faults are present throughout the axial basins (San Marcial, Engle, and Palomas basins) of the Rio Grande rift north and south of Truth or Consequences. The times of movement on these faults are largely unknown owing to their maturity (highly degraded) and potential for rapid burial in upslopefacing positions. However, their morphology is comparable to or more subdued than 100-ka fault scarps in southern Arizona and Utah, suggesting that the most recent activity may have been in late-middle Pleistocene time (i.e., 130$250 \mathrm{ka}$ ) on intrabasin faults in this part of the rift. 


\section{REFERENCES CITED}

Aldrich, M.J., and Laughlin, A.W., 1982, Orientation of least-principal horizontal stress: Arizona, New Mexico, and the Trans-Pecos area of West Texas: Los Alamos National Laboratory Publication LA-9158-Map UC-11, map scale $1: 1,000,000$.

Bachman, G.0., and Mehnert, H.H., 1978, New K-Ar dates and the 1 ate Pleistocene to Holocene geomorphic history of the central Rio Grande region, New Mexico: Geological Society of America Bulletin v. 89, p. 283-292.

Baldridge, W.S., Bartov, Y., and Kron, A., 1983, Geologic map of the Rio Grande rift and southeastern Colorado Plateau, New Mexico and Arizona, in Riecker, R.E., ed., Rio Grande rift--Tectonics and magmatism: Washington, D.C., American Geophysical Union, 2nd printing (1982), map scale $1: 500,000$.

Birkeland, P.W., 1984, Soils and Geomorphology: New York, Oxf ord University Press, $372 \mathrm{p}$.

Bucknam, R.C., 1980, Characteristics of active faults in the Great Basin, in Summaries of Technical Reports, v. 9, National Earthquake Hazards Reduction Program: U.S. Geological Survey Open-File Report 80-6, p. 9494.

Bucknam, R.C., and Anderson, R.E., 1979, Estimation of fault-scarp ages from a scarp-height-slope-angle relationship: Geology, v. 7, no. 1, p. 11-14.

Chapin, C.E., 1978, Overview of Cenozoic features, San Marcial basin, in Hawley, J. W., compiler, Guidebook to Rio Grande rift in New Mexico and Colorado: New Mexico Bureau of Mines and Mineral Resources Circular 163, p. 96-97.

1979, Evolution of the Rio Grande rift--A summary, in Riecker, R.E., ed., Rio Grande rift--Tectonics and magmatism: Washington, D.C., American Geophysical Union, p. 1-5.

Chapin, C.E., Chamberlain, R.M., Osburn, G.R., Sanford, A.R., and White, D.W., 1978, Exploration framework of the Socorro geothermal area, New Mexico, in Chapin, W.E. and Elston, W.E., eds., Field guide to selected cauldrons and mining districts of the Datil-Mogollon volcanic field, New Mexico: New Mexico Geological Society Special Publication no. 7, p. 115-129.

Chapin, C.E., and Seager, W.R., 1975, Evolution of the Rio Grande rift in the Socorro and Las Cruces areas, in Seager, W.R., Clemons, R.E., and Callender, J.F., eds., Guidebook of the Las Cruces country: New Mexico Geological Society Guidebook, 26th Field Conference, p. 297-321.

Clemons, R.E., King, W.E., and Mack, G.H., eds., 1986, Truth or Consequences Region [New Mexico]: New Mexico Geological Society Guidebook, 37th Field Conference, $317 \mathrm{p}$. 
Clemons, R.E., and Osburn, G.R., 1986, Geology of the Truth or Consequences area, in Clemons, R.E., and others, eds., Truth or Consequences Region: New Mexico Geological Society Guidebook, 37th Field Conference, p. 69-81.

Coney, P.J., 1976, Structure, volcanic stratigraphy, and gravity across the Mogollon Plateau, New Mexico: New Mexico Geological Society, Special Publication 5, p. 29-41.

Cook, F.A., McCuller, D.B., Decker, E.R., and Smithson, S. B., 1979, Crustal structure and evolution of the southern Rio Grande rift, in Riecker, R.E., ed., Rio Grande rift--Tectonics and magnetism: Washington D.C., American Geophysical Union, p. 195-208.

Dane, C.H., and Bachman, G.0., 1965, Geologic map of New Mexico: U.S. Geological Survey Map, map scale 1:500,000.

Elston, W.E., and Bornhorst, T.J., 1979, The Rio Grande rift in context of regional post-40 M.Y. volcanic and tectonic events, in Riecker, R.E., ed., Rio Grande rift--Tectonics and magmatism: Washington D.C., American Geophysical Union, p. 416-438.

Fitzsimmons, J.P., 1955, ed., Guidebook to south-central New Mexico: New Mexico Geological Society Guidebook, 6th Field Conference, 193 p.

Gile, L.H., 1986, Late Holocene displacement along the Organ Mountains fault in southern New Mexico--A summary: New Mexico Geology, v. 8, no. 1, p. $1-4$.

1987, Late Holocene displacement along the Organ Mountains fault: New Mexico Bureau of Mines and Mineral Resources Bulletin 116, $43 \mathrm{p}$.

Gile, L.H., Hawley, J.W., and Grossman, R.B., 1981, Soils and geomorphology in the Basin and Range area of southern New Mexico--Guidebook to the desert project: New Mexico Bureau of Mines and Mineral Resources Memoir 39, $222 \mathrm{p}$.

Hawley, J.W., compiler, 1978, Guidebook to the Rio Grande rift in New Mexico and Colorado: New Mexico Bureau of Mines and Mineral Resources Circular $163,241 \mathrm{p}$.

Hawley, J.W., Bachman, G.O., and Manley, Kim, 1976, Quaternary stratigraphy in the Basin and Range, Southern Rocky Mountains, and Great Plains Provinces, New Mexico and western Texas, in Mahaney, W.C., ed., Quaternary stratigraphy of North America: Stroudsburg, Pa., Dowden, Hutchinson, and Ross, p. 235-274.

Hawley, J.W., and Kottlowski, F.E., 1969, Quaternary geology of the southcentral New Mexico border region, in Kottlowski, F.E., and Lemone, D.V., eds., Border stratigraphy symposium: New Mexico Bureau of Mines and Mineral Resources Circular 104, p. 89-115. 
Hawley, J.W., Kottlowski, F.E., Strain, W.S., Seager, W.R., King, W.E, and Lemone, D.V., 1969, The Santa Fe Group in south-central New Mexico border region, in Kottlowski, F.E., and Lemone, D.V., eds., Border stratigraphy symposium: New Mexico Bureau of Mines and Mineral Resources Circular 104 , p. 52-76.

Hawley, J.W., and Seager, W.R., 1978, New Mexico-Texas state line to Elephant Butte Reservoir, in Hawley, J.W., compiler, Guidebook to Rio Grande rift in New Mexico and Colorado: New Mexico Bureau of Mines and Mineral Resources Circular 163, p. 71-89.

Heyl, A.V., Maxwell, C.H., and Davis, L.L., 1983, Geology and mineral deposits of the Priest Tank quadrangle, Sierra County, New Mexico: U.S. Geological Survey Miscellaneous Field Studies Map MF-1665, map scale $1: 24,000$.

Jacobs, R.C., 1956, Geology of the central front of the Fra Cristobal Mountains, Sierra County, New Mexico: Albuquerque, University of New Mexico, unpublished M.S. thesis, $47 \mathrm{p}$.

Jahns, R.H., 1955, Geology of the Sierra Cuchillo, New Mexico, in Fitzsimmons, J. P., ed., Guidebook of south-central New Mexico: New Mexico Geological Society Guidebook, 6th Field Conference, p. 158-174.

Jahns, R.H., McMillan, D.K., O'brient, J.D., and Fisher, D.L., 1978, Geologic section in the Sierra Cuchillo and flanking areas, Sierra and Socorro Counties, New Mexico, in Chapin, C.E., and Elston, W.E., eds., Field guide to selected cauldrons and mining districts of the Datil-Mogolion volcanic field, New Mexico: New Mexico Geological Society Special Publication 7 , p. 131-138.

Kelley, V.C., 1955 , Regional tectonics of south-central New Mexico, in Fitzsimmons, J.P., ed., Guidebook of south-central New Mexico: New Mexico Geological Society Guidebook, 6th Field Conference, p. 96-104.

Kelley, V.C., and Silver, Caswell, 1952, Geology of the Caballo Mountains, Nev! Mexico: University of New Mexico Press Publications in Geology 4, $286 \mathrm{p}$.

Kottlowski, F.E., 1955, Geology of the San Andres Mountains, New Mexico, in Fitzsimmons, J.P., ed., Guidebook of south-central New Mexico: New Mexico Geological Society Guidebook, 6th Field Conference, p. 137-145.

Laughlin, A.W., Aldrich, M.J., and Vaniman, D.T., 1983, Tectonic implications of mid-Teritary dikes in west-central New Mexico: Geology, v. 11, p. 45-48.

Lipman, P.W., 1983, Cenozoic magmatism associated with extensional tectonics in the Rocky Mountains: Geological Society of America Abstracts with Programs, v. 15, no. 5, p. 288.

Lozinsky, R.P., 1986, Geology and late Cenozoic history of the Elephant Butte area, Sierra County, New Mexico: New Mexico Bureau of Mines and Mineral Resources Circular 187, 40 p., 2 plates, map scale 1:25,000. 
1987, Cross section across the Jornada del Muerto, Engle, and northern Palomas Basins, south-central New Mexico: New Mexico Geology, v. 9, no. 3, p. 55-57, 63.

Lozinsky, R.P., and Hawley, J.W., 1986, Upper Cenozoic Palomas Formation of south-central New Mexico, in Clemons, R.E., and others, eds., Truth or Consequences Region: New Mexico Geological Society Guidebook, 37 th Field Conference, p. 239-247.

Lozinsky, R.P., Kelley, J.C., Osburn, G.R., and Kudo, A.M., 1986, Boat log for southern half of Elephant Butte Reservior, in Clemons, R.E., and others, eds., Truth or Consequences Region: New Mexico Geological Society Guidebook, 37th Field Conference, p. 57-68.

Lucas, S.G., and Oakes, Wayne, 1986, Pliocene (Blancan) vertebrates from the Palomas Formation, south-central New Mexico, in Clemons, R.E., and others, eds., Truth or Consequences Region: New Mexico Geological Society Guidebook, 37th Field Conference, p. 249-255.

Machette, M.N., 1978, Geologic map of the San Acacia quadrangle, Socorro County, New Mexico: U.S. Geological Survey Quadrangle Map GQ-1415, map scale $1: 24,000$.

1985, Calcic soils of the southwestern United States, in Weide, D.L., ed., Soil and Quaternary geology of the southwestern United States: Geological Society of America Special Paper 203, p. 1-21.

1986, History of Quaternary of fset and paleoseismicity along the La Jencia fault, central Rio Grande rift, New Mexico: Bulletin of the Seismological Society of America, v. 76, no. 1, p. 259-272.

1987a, Neotect onics of the Rio Grande rift, New Mexico: Geological Society of America Abstracts with Programs, v. 19, no. 7, p. 754.

1987b, Preliminary assessment of paleoseismicity at White Sands Missile Range, southern New Mexico--Evidence for recency of faulting, fault segmentation, and repeat intervals for major earthquakes in the region: U.S. Geological Survey Open-File Report 87-444, 46 p., $19 \mathrm{figs,}$ and 2 tables.

Machette, M.N., and Colman, S.M., 1983, Age and distribution of Quaternary faults in the Rio Grande rift--Evidence from morphometric analysis of fault scarps: Geological Society of America Abstracts with Programs, v. 15 , no. 5 , p. 320 .

Machette, M.N., and McGimsey, R.G., 1983, Map of Quaternary and Pliocene faults in the Socorro and western part of the Fort Sumner $1^{\circ} \times 2^{\circ}$ quadrangles, central New Mexico: U.S. Geological Survey Miscellaneous Field Studies Map MF-1465-A, map scale 1:250,000.

Machette, M.N., and Personius, S.F., 1984, Map showing Quaternary and Pliocene faults in the east part of the Aztec $1^{\circ} \times 2^{\circ}$ quadrangle and west part of the Raton $1^{\circ} \times 2^{\circ}$ quadrangle, northern New Mexico: U.S. Geological Survey Miscellaneous Field Studies Map MF-1465-B, map scale 1:250,000. 
Machette, M.N., Personius, S.F., Menges, C.M., and Pearthree, P.A., 1986a, Map showing Quaternary and Pliocene faults in the Silver City $1^{\circ} \times 2^{\circ}$ quadrangle and the Douglas $1^{\circ} \times 2^{\circ}$ quadrangle, southeastern Arizona and southwestern New Mexico: U.S. Geological Survey Miscellaneous Field Studies Map MF-1465-C, map scale 1:250,000.

Machette, M.N., Personius, S.F., and Nelson, A.R., 1986b, Late Quaternary segmentation and slip-rate history of the Wasatch fault zone, Utah: EOS, v. 67 , no. 44, p. 1107 .

Machette, M.N, Personius, S.F., and Nelson, A.R., 1987, Quaternary geology along the Wasatch fault zone--segmentation, recent investigations, and preliminary conclusions, in Hays, W.W., and Gori, Paula, eds., Assessment of regional earthquake hazards along the Wasatch Front, Utah: USGS OpenFile Report $87-585,72$ ms p., 5 figs., 3 tables.

Maldonado, Florian, 1980, Geologic map of the northern part of the Sierra Cuchillo, Socorro and Sierra Counties, New Mexico: U.S. Geological Survey Open-File Report 80-230, map scale $1: 24,000$.

Maxwell, C.H., and Heyl, A.V., 1976, Preliminary geologic map of the Winston quadrangle, Sierra County, New Mexico: U.S. Geological Survey Open-File Report 76-858, map scale $1: 24,000$.

Maxwell, C.H., and Oakman, M.R., 1986, Geologic map and cross sections of the Cuchillo quadrangle, Sierra Ccunty, New Mexico: U.S. Geological Survey Open-File Report 86-279, map scale $1: 24,000$.

McCleary, J.T., 1960, Geology of the northern part of the Fra Cristobal Range, Sierra and Socorro Counties, New Mexico: Albuquerque, University of New Mexico, unpublished M.S. thesis, $59 \mathrm{p}$.

Muehlberger, W.R., 1979, The Embudo fault between Pilar and Arroyo Hondo, New Mexico--An active intracontinental transform fault, in Ingersoll, R. A., ed., Guidebook to Santa Fe Country: New Mexico Geological Society Guidebook, 30th Field Conference, p. 77-82.

Nakata, J.K., Wentworth, C.M., and Machette, M.N., 1982, Quaternary fault map of the Basin and Range and Rio Grande rift provinces, Western United States: U.S. Geological Survey Open-File Report 82-579, map scale $1: 2,500,000$.

Nash, D.B., 1981, FAULT--A Fortran program for modelling the degradation of active normal fault scarps: Computers and Geosciences, v. 7, p. 249-266.

Nelson, E.P., 1986, Geology of the Fra Cristobal Range, south-central New Mexico, in Clemons, R.E., and others, eds., Truth or Consequences Region: New Mexico Geological Society Guidebook, 37th Field Conference, p. 83-91.

Pearthree, P.A., and Calvo, S.A., 1987, The Santa Rita fault zone--Evidence for large magnitude earthquakes with very long recurrence intervals, Basin and Range Province of southeastern Arizona: Bulletin of the Seismological Society of America, v. 77, p. 97-116. 
Pierce, K.L., and Colman, S.M., 1986, Effect of height and orientation (microclimate) on geomorphic degradation $r$ ates and processes, lateglacial terrace scarps in central Idaho: Geological Society of America Bulletin, v. 97, p. 869-885.

Ramberg, J.B., Cook, F.A., and Smithson, S.B., 1978, Structure of the Rio Grande rift in southern New Mexico and west Texas based on gravity interpretation: Geological Society of America Bulletin v. 89, no. 1, p. 107-123.

Reppenning, C.A., and May, S.R., 1986, New evidence for the age of the lower part of the Palomas Formation, Truth or Consequences, New Mexico, in Clemons, R.E., and others, eds., Truth or Consequences Region: New Mexico Geological Society Guidebook, 37th Field Conference, p. 257-260.

Riecker, R.E., 1979, ed., Rio Grande Rift--Tectonics and Magmatism: Washington, D.C., American Geophysical Union, 438 p.

Scott, W.R., McCoy, W.D., Shroba, R.R., and Rubin, Meyer, 1983, Reinterpretation of exposed record of the two last cycles of Lake Bonneville, Western United States: Quaternary Research, v. 20, no. 3, p. 261-287.

Seager, W.R., 1980, Quaternary fault system in the Tularosa and Hueco basins, southern New Mexico and West Texas, in Dickerson, P.W., and Hof fer,J.M., eds., Trans-Pecos Region, southeastern New Mexico and West Texas: New Mexico Geological Society Guidebook, Thirty-first Field Conference, p. 131-135.

1981, Geology of the Organ Mountains and southern San Andres Mountains, New Mexico: New Mexico Bureau of Mines and Mineral Resources Memoir 36, 97 p., 4 plates, map scale $1: 31,250$

Seager, W.R., and Morgan, Paul, 1979, Rio Grande rift in southern New Mexico, west Texas, and northern Chihuahua, in Riecker, R.E., ed., Rio Grande rift--Tectonics and magmatism: Washington D.C., American Geophysical Union, p. 87-106.

Seager, W.R., Clemons, R.E., and Callender, J.F., eds., 1975, Guidebook of the Las Cruces country: New Mexico Geological Society Guidebook, 26th Field Conference, $376 \mathrm{p}$.

Seager, W.R., Clemons, R.E., Hawley, J.W., and Kelley, R.E., 1982, Geol ogy of the northwest part of the Las Cruces $1^{\circ} \times 2^{\circ}$ sheet, New Mexico: New Mexico Bureau of Mines and Mineral Resources Geologic Map 53, 3 sheets, map scale $1: 125,000$.

Seager, W.R., Hawley, J.W., Kottlowski, F.E., and Kelley, S.A., 1987, Geology of east half of Las Cruces and northeast El Paso $1^{\circ} \times 2^{\circ}$ sheets: New Mexico Bureau of Mines and Mineral Resources Geologic Map 57, 3 plates, map scale $1: 125,000$.

Seager, W.R., Shafiqullah, M., Hawley, J.W., and Marvin, R.F., 1984, New K-Ar dates from basalts and the evolution of the southern Rio Grande rift: Geological Society of America Bulletin, v. 95, no. 1, p. 87-99. 
Strain, W.S., 1966, Blancan mammalian fauna and Pleistocene formations, Hudspeth County, Texas: University of Texas at Austin, Texas Memorial Museum Bulletin 10, $55 \mathrm{p}$.

Thompson, Sam, 1955, Geology of the Fra Cristobal Range, New Mexico, in Fitzsimmons, J. P., ed., Guidebook of south-central New Mexico: New Mexico Geological Society Guidebook, 6th Field Conference, p. 155-157.

1978, The Fra Cristobal Range from Mitchell Point exit, in Hawley, J.W., compiler, Guidebook to Rio Grande rift in New Mexico and Colorado: New Mexico Bureau of Mines and Mineral Resources Circular 163, p. 93-96.

Van Allen, B.R., Wilson, J.L., and Hunter, J.C., 1984, Sunset Ridge fluorite deposit, Fra Cristobal Range, Sierra County, New Mexico: New Mexico Geology, v. 6, no. 1, p. 1-12.

Wallace, R.E., 1977, Profiles and ages of young fault scarps, north-central Nevada: Geological Society of America Bulletin, v. 88, no. 9, p. 12671281.

Warren, R.G., 1978, Characterization of the lower crust-upper mantle of the Engle basin, Rio Grande rift, from a petrochemical and field geologic study of basalts and their inclusions: Albuquerque, University of $\mathrm{New}$ Mexico, unpublished M.S. thesis, $156 \mathrm{p}$.

Woodward, L.A., Callender, J.F., Seager, W.R., Chapin, C.E., Gries, J.C., shaffer, W.L., and Zilinski, R.E., 1978, Tectonic map of the Rio Grande rift region in New Mexico, Chihuahua, and Texas, in Hawley, J.W. compiler, Guidebook to Rio Grande rift in New Mexico and Colorado: New Mexico Bureau of Mines and Mineral Resources Circular 163, map scale $1: 1,000,000$.

Zoback, M.L., and Zoback, Mark, 1980, State of stress in the conterminous United States: Journal of Geophysical Research, v. 85, no. B11, p. 61136156.

Zoback, M.L., Anderson, R.E., and Thompson, G.A., 1981, Cainozoic evolution of the state of stress and style of tectonism of the Basin and Range province of the western United States: Philosophical Transactions of the Royal Society of London, series A, v. 300, p. 407-434. 